University of Louisville

ThinkIR: The University of Louisville's Institutional Repository

Electronic Theses and Dissertations

1947

\title{
Characteristics of a falling film distillation column.
}

Edward J. Kimmel 1920-

University of Louisville

Follow this and additional works at: https://ir.library.louisville.edu/etd

Part of the Chemical Engineering Commons

\section{Recommended Citation}

Kimmel, Edward J. 1920-, "Characteristics of a falling film distillation column." (1947). Electronic Theses and Dissertations. Paper 2000.

https://doi.org/10.18297/etd/2000

This Master's Thesis is brought to you for free and open access by ThinkIR: The University of Louisville's Institutional Repository. It has been accepted for inclusion in Electronic Theses and Dissertations by an authorized administrator of ThinkIR: The University of Louisville's Institutional Repository. This title appears here courtesy of the author, who has retained all other copyrights. For more information, please contact thinkir@louisville.edu. 


\title{
UITVE ITYG \\ $+i$
}

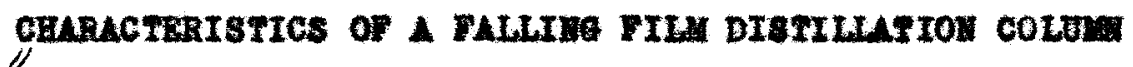

\author{
A Theis: \\ Submitted to the Faoulty \\ of the Graduate Sohool \\ of the Univereity of Loul owlle \\ 14 Rartial Raleilinont \\ of the Aequiromente \\ for the Bogres of

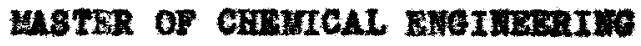

Dopartmont of Choniond Raginooring

Daward I. Timal

Haroh, 1947 
This PDF document is a scanned copy of a paper manuscript housed in the University of Louisville (UofL) Libraries. The quality of this reproduction is greatly dependent upon the condition of the original paper copy. Indistinct print and poor quality illustrations are a direct reflection of the quality of materials that are available for scanning. The UofL Libraries greatly appreciates any better copies that can be made available for replacement scans. 


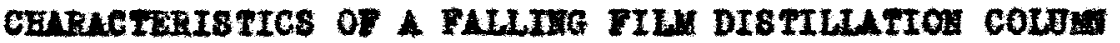

Edmatd J. amme1

Approwe by the Examining Cownt the.

\begin{tabular}{l} 
Direotor $\quad$ G. C. Williams \\
$\frac{\text { Guy Stevenson }}{\text { R. C. Ernst }}$ \\
\hline
\end{tabular}

Laroh, 1947 
TABLE of COMTEWT

Page

Liat of Tables

17

List of Figures

$\boldsymbol{\nabla}$

Abetrat

$\mathbf{v}$

Intreduetion

2

Higtorieal

6

Theoretioal

6

Bxpertumatal

12

Summery and Conolusione

10

Lterature Gited

44

Appondix

46

Leknowledgmint

64

Vita

66 
Table I Rotanoter Calibration Data

Table II External Heat Loes Data 18

Table III Swanary Data for Fator Rune 22

Table IV Summiry Data for Aleohol kiwe so

Table $T$ Tabulated Data for Correlation $I$

rable II Tabulated Date for Correlation III 37

Tablo VI Phyoleal Hoacuromonte on Filn Type Dietillation Jnit 46

Table VIII Swmary Compericon of Induetrial Beer stripping

Equipwent

Table IX sample Caloulation

Table $x$ Tabulated Date for Wator Ruas

*. Rates and Temperatures 52

b. Enat Tranefor for staam side 65

- Heat tranafor for Liquid side 58

Table XI Tabulated Data for Aleohol Rune 61 
LIST OF PIGURES

Page

Figure 1 Flow Dagram of Falling P11m st111 28

Nigare 2 Rotamotor Cailibration Curve 17

Figure 8 External Heat Lose Curw 19

F1gure 4 Sample Data shoet 21

Figure 5 Comparioen of Overall Hent Trancfer Coeffiolonte 26

Baged on Liquid siae and steam Side Bnthalpies

Figure 6 Ovorall Heat Tranufer Coefflelent Vereus Fead 27

Rate for Fater Ruas

Figure 7 Overall Heat Iranufor Coefflalent Veraue Feed

Rate for Ethanol Rune

Figure 8 Correletion, Aotual Veroue Celoulated

"Bottom" Compoultion

Pigare 9 Correlation, Log-log Plot of Lotual Verous 35

Caloulated "Bottom" Compoltion 35

Hgure 10 Number of Theoretion Plates at fotal Reflux 38

Versue Feed Rate

Figure 11 Comparison of Folling Milm Beatere

Pigure 12 Produet Rate Veroul Colwa superfielal Tapor

Volooity 68 
ABstuck

Tho ohareoterietion of a Malling Filu Diatillation Colwa are presented. The work undortaken by the witer has been IIndted to the etudy of a colum of fixed leagth and diamoter vender the condition: of atmosphorie presoure. Iloat trancfor otudies hare been oenduoted on the syotem of wator and on varying componitions of ethenol-water in an attengt to evaluate the quantitative factors on a pllot plant alsed NIn otill wo that the denlga of a comoroial alcohol unit wight bo attempted. 
The euthor withe to ackmomledge

the kind assietanos and helpful guidanoo

of Dr. Gordon G. WIILIan,

whe direeted this retearoh. 
Inrrobtrerron 
Dp to the present time number of typec of alotiliatlon

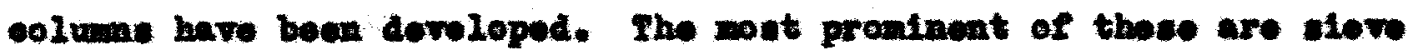
plate and babble eap untes. The aleve plate 1 the eimplor of the two and conclete of a vertion tomer of punehod platea whor Liquid 1. conteoted by vepor to effeot a material interchange. The bubble eap towor is a type in whioh an attongt is male to inprove rruotionatien by a wore intimate and lenger contaet botwoon liquid and repor.

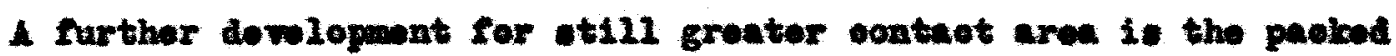
tower. In which greator intimay of contet lo obtuinod by pacaling the vapor over oven greater surfuce aroal for the sabe tomor volume. The packed tower differs from the firat two in that tho conoentration gradient is gradun from top to bottom Inotead of otopuleo. Hore modern otill donigne are baced on thoorles formulated

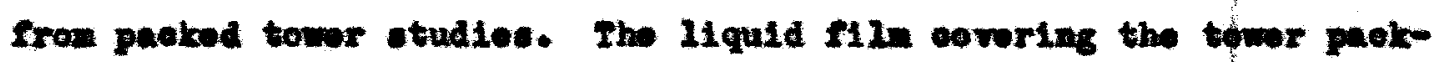

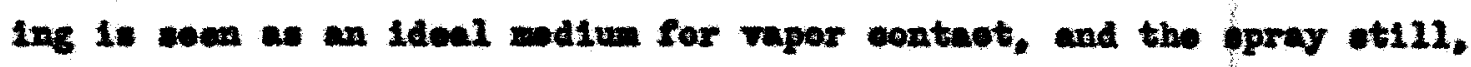

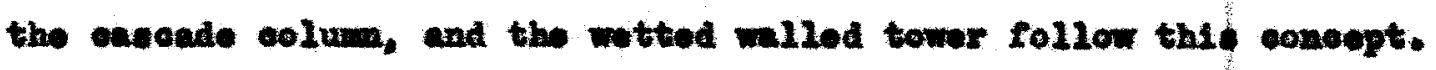

Eaoh donign had ite own oharaotorictios and it woon ohanneled to indurtrial rielde favering the apeeial attributee of

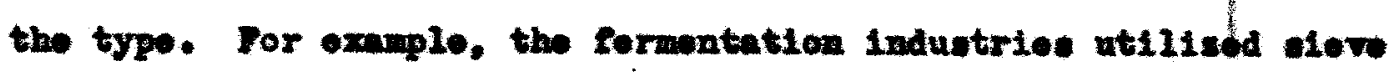
plete oolumey the petrolewi Induotries ned batoh etille and bubble tray tomore. Oae reacon for the formor wat the sultability of the ciew plate for handling a liquid of relatively high oolide eontent. whereal the bubble eap walt wae nore readily adaptable for useges ontalling nogligible solide nateriale whore high frootionation effieleney we demended. In flelde whore low abolute proceures were 
noweseary and little entralwagt lose could be toleratod, the opray at121 was introduoed. It we only partially ancoesaful booause of ite Inability to reduce ontralmant. Wintonanos coote also ran higher than expeoted, and the einplifled design omorged we a casede or baffle plate still.

The bafrie or eavoude type completely olininated the disadvantage of the wite formation in a epray atill, but with the advent of

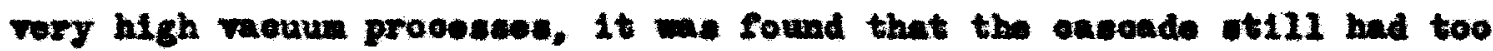
Migh a presure drop own though it wie oonelderably boliow that of preVoue plate colum dealgas. The next and probably latest dealgn of

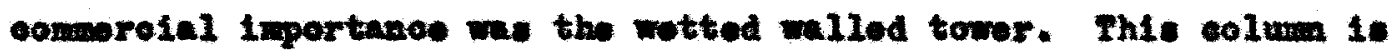
eimilar to a tubular fin type oraporator, and although there is little Information on this apparatus in the field of distiliation, it is comcel wable that date nay be utilised from that of evaporation for eertain dealgn faotora. Hewever, far too 11ttlo information is avaliable in the literature cowering this important pieoe of equipaont, and it is the purpose of this investigation to otudy tho oharectoriatios of a riln bype distillation colum from tho otandpoint of hout and anterial Interahange.

The falling film type of distillation unit is concldored elaoe It way be on ldeal unit for the removal of aloohol from the beer formal In the farmentation of cereal gralns. Reeent advanese in the weohol Inductry have show the Inportanee of low temperature beer otripping.

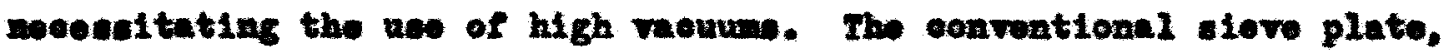
grid paoked, and ring packed oolumas, have proved eomparatively poor in 


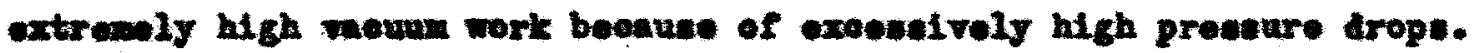
The falling Aln type of ettll beanes of the froe vapor epaes obvioualy ahteves the maimen in presure irop through the oolund longth, Cortaln oolum paeking mterials, particulerly wood eride.

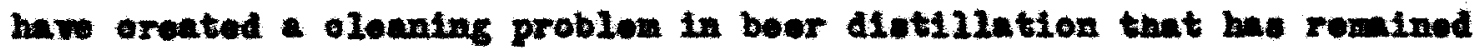
uncelved after many yoars of straly. It soom that the sollde In the

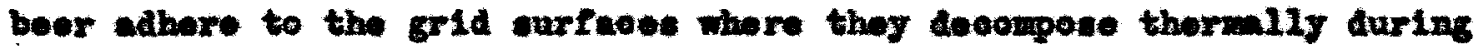
operation, thoroby imparting Lisagreable odore and/or tente to the distillato. This faeter may be oliminited by the rilm typo unit with the elinination of a paking to beoone fouled and irregular aurthon to pornt build-up of collds.

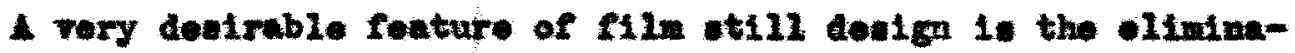
tion of the dilution offect eavabd by varged atean which is normally present in the conwontional beor etill. Thi foature pormits a maximan ratio of aleohol to water during proceseing and thereby lnereaces the otoan evoniong.

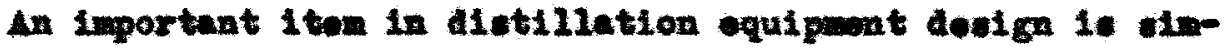
pllelty of contruotion and walatenunoe. The falling film otill is of relatively inple design in comparieon with othor beer coluane.

A find feeture of the film type eoluma met be omplacised. Thore have ben heat tranifor ooseflefento reported in the 11 tarature (I)

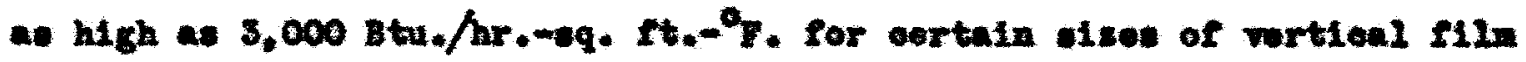
hoatora. Such a coeffielent would offect an coonong that could bo roalisod as in no othor beor etrippling unit. This foature already had been realised on short tube fllm boilers. 
GIstorrcal 
A f1In otill wy be dofined as a wat in wioh freotionation

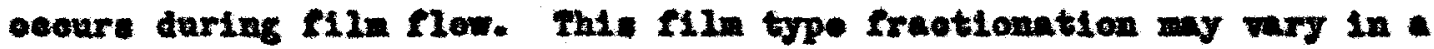
number of wye. doponding on the mennor of introduetng feod, the mothod

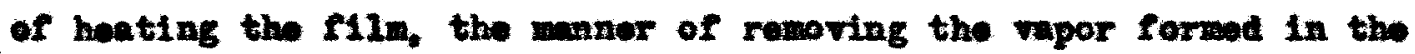
proeses, and the subequont removil or rorlux of the condensed overhoal rapor.

The major portion of the date in the literature at precent has

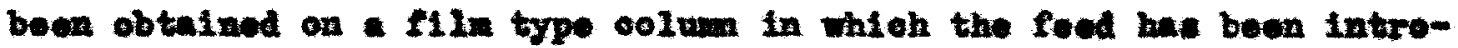
duoed as a vepr from a roboller to the bese seotion, while the overhed repor the beon condeneed and roturned an totel reflux $(2,3,4,5,6)$, With such a syotom, one of the usual mothods of oolume oraluation zy be

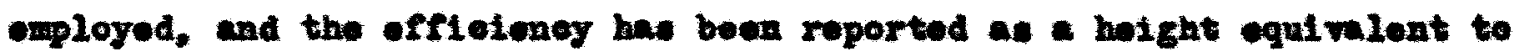
a thooretian plate (H.E.I.P.), a bolght of a trancfer nut (H.T.J.), a number of theoretieal plates at total reflux, or wom type of oorrelatias equation invelving film reoletanoes, hoat, or material trancfere. The problen undertalion by the author in this tholls wa the -raluation of oolum performanos under pontble plent operating oonditione of Ilquid feed to the top of the colvan, reporination by jeokoted eteckn, cbanes of reflux, and lingle pastege of muterial-in-prooes through the ooluw. Comparablo oporating oonditions aro not represented among data araliable in the literature. 
THERETICAL 
The enet mechanien. of heat tranefor for fill type distillation

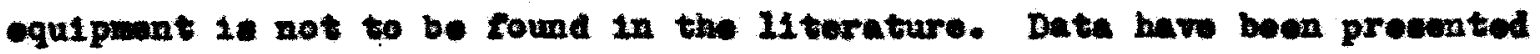

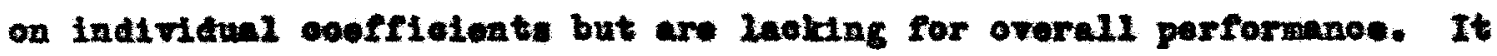
1. peasible, howerer. for one to postulate mochantam by the uee of quantitative relations that have evolved from studies on film hoaters. The Wueselt equation ( 7$)$ has aproximated conditions in the film hoter and 10

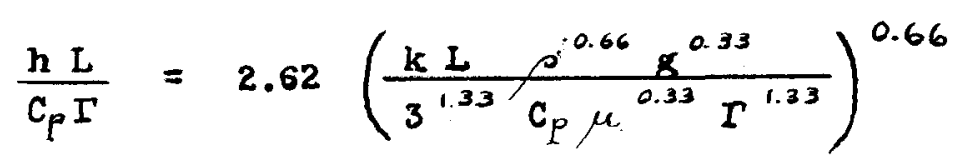

where $h=11$ quid rilm oocrlolent Btu./mr.-eq. It.-OP. $L=$ hoight of pipe, N.

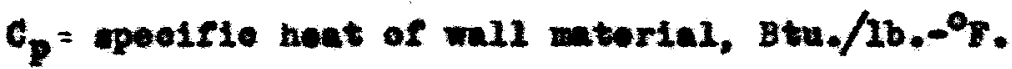
$\Gamma=$ Iuid rate, Ino/hr.-rt. $z=$ thormal conduetirity, Btu./hr,-eq.ft, $-0 \mathrm{~g} / \mathrm{ft}$, of tube wall. $\rho=$ donelty of eluid, 2bo./ou. .t. $\mathrm{G}$ = aceoleration of granty. ft./eq. hr. $\mu=$ Iuid vimoonity, Ibo./hr.-rt.

It is ceos from this equation that the individual hot tranafor coefficlent viriee direotiy as the feed rate, and invereely at the ooluon length and atoan preacure (or temperature drop between hoting molum and Iiquid (12i). Ints oan bo expeoted to hold approximately for the overall tranafer of heat, as the leagth of the ooluwa uced in thoes studies alght be sonuldored abnormally high in coxparieon with that of 
the film haters reported.

For the dietillation thoory Involved in the etudy, poselble mochanian mat be reviewed. A batoh distillation quantitative relationchlp nay be coneidared inttially. By definition, batoh distiliation is a proces in which portion of material is oharged to a pot, cubjeoted to heat, and, ugon raporisation, is rowored lmoditety and condencod. Tho

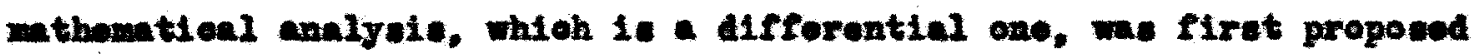
by Rayleigh (8). The relationohip bo prounted was that the logarithe of

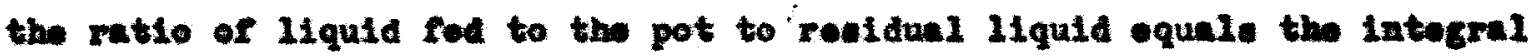
vilue of $\mathrm{ax} /(y-x)$, whore $x=$ the somponition of the liquid and $y=$ the rapor compostion in equilibrium ath the liguld. The linite are taken betweon the compostion of the residual charge and the original oharge with reforenoe to the more volatilo oomponent. Tht roletion is oudiy eraluated by mons of graphioel intogration.

Hodern exponente of oontinnous proseseing teohniques state that

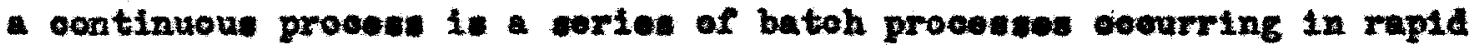

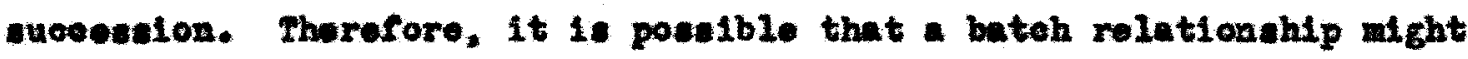
approximet the reault obtalned by oontinuoue prooseding. particularly In a filn type columa.

If equilibrian is esenued to be obtained in eqeh area of a flim et111. the relatienchip would be that for equilibriun distiliation. The gantitative study of suoh a propese would dowand the ves of a graphieal proosdure with the equilibriun diegram.

It 1. reaponable to expeot that the meobnian of filn type Alatillation in intermodiate botwoen the two extromos of bateh distillation 
and trae equillbrium diatillation. There he been some oridence to shor that the meohens an of film of wotted will dietillation epproachos more olosely the betoh type ovaluation. This aimilarity is indieated in the

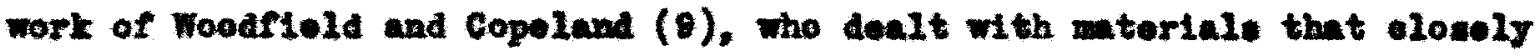
adhered to Racult". Iar. Ono object of the present Investigation in to determine the valldity of the theory or the degree of divorgenoe from it. 


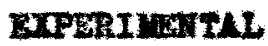


The apparatue for this inveatigation was a otoam-jeoloted copper tube 2.988 inohos inalde diameter by 15.20 foot in longth (woo P1g. 1). The upper portion of the hoting ourface had an 8 inoh calning eootion, the upper odge of whioh wan notohod as a wr, and over whioh feed to the celum eould be dietributed. The bace of the colum wa fittod with liquld-ceal vpor trap through whioh strippod liquid pased to a "bottome" reopiver. It mas very important that the wall carface be perfeotly vertion, therefore alub line was arranged alongelde the colwa. The extermal wurface of the ealuwa wa not lagged and thorefore

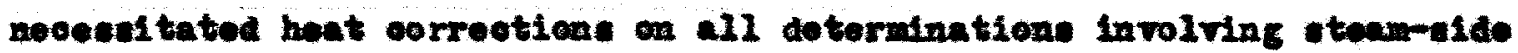
bent trencfor eoeffielent:e.

Ono of the mout orition faotor involved in film atill operation 1. 11quid dietribution to the columa. A welr arrengement was unod in thle work. This wolr was 10 donigned that $10 \mathrm{v}$ notohos, $2^{n}$ doep. wore evenly epeed around the upper edge of a 5 inch oopper tube. The peinte jutting upward from this seotion were beat outmard so that they Iay on the elroumference of a cirele of the Inoh dimeter. Thit opreading of pointe acoomplishod a rather awooth Flor of IIquid into the colvm Wh the peroeptible ohannoling orfeot.

After the liquid was opread in a unifor flln, bolling ocenrred. The vaper moved up the oolum, left the untt throngh a ver line, and paseed through an ontraineont soparator into the top of tho condoncor. The distillate left the condencer at the botton through a non-oondenmablea vont bottle and flowed inte a "tope" product rooelver.

By proliminary inopotion, it we observed that a comple to and 


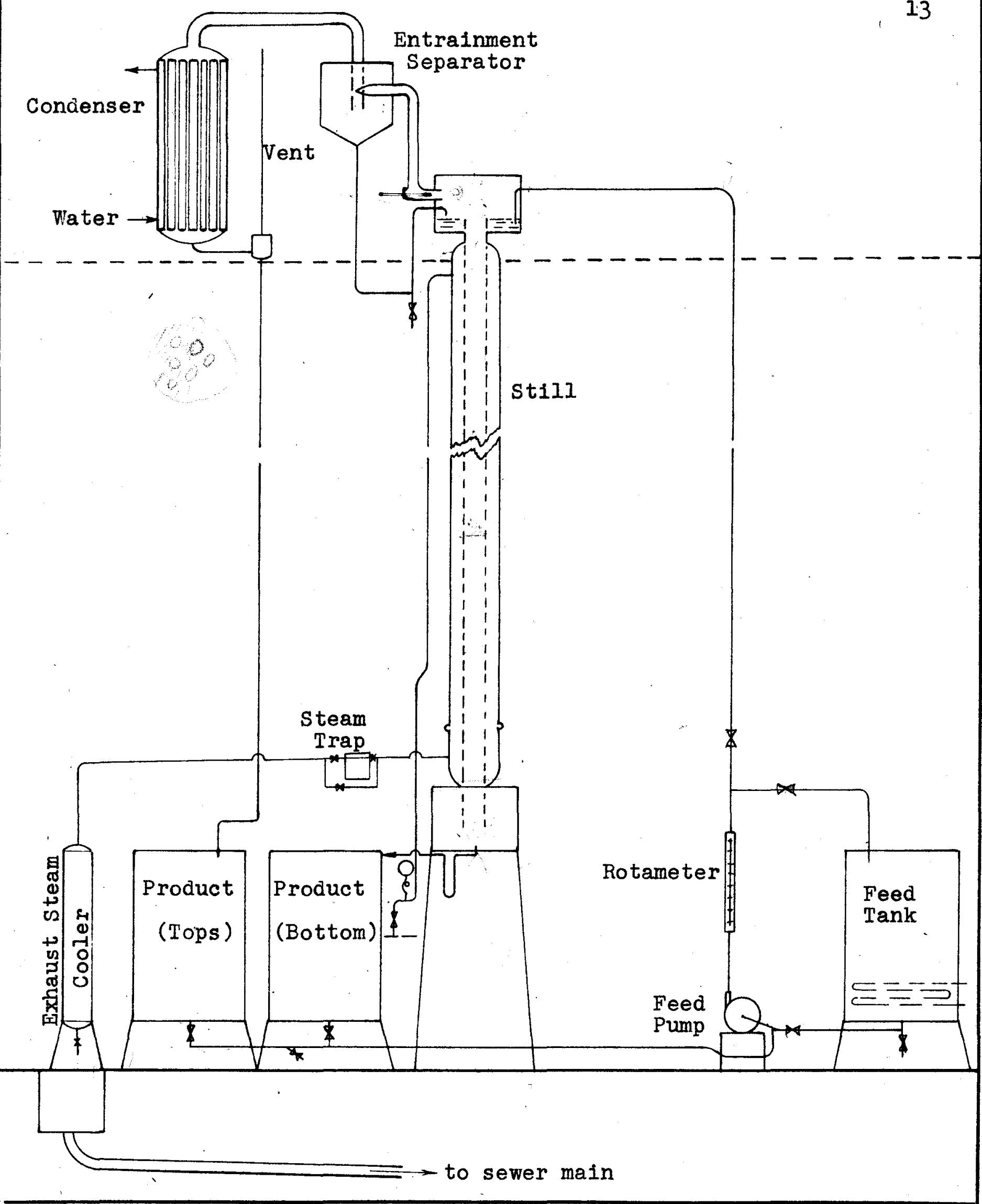

Fig. 1. Flow Diagram of Faling Film Still. 
miform film could be formod, at long as no bolling oceurred with a food of leas than 5 gallone per hour, however, whon bolling oocurred, a feed rate allghtly over 5 gallens por hour we required.

In the study of the hoat trangfor charaterieties of the riln 00lum, water was oharged to a food pot and hoatod by a atean ootl to the dealred tomperature. This feod pot we fitted with a reelroulation lino to diatribute the heat throughout the bateh of Iiquid. The feed was trencforred from the pot by a contrifugal puxp to the upper soction of the f1In at111, thenes into the had of the colume overflowing the wir, and paseing in a ufform film down the oolum. The Iiquid was raised to the boliting point and partially mporized with the rapor paseing up the 0olum. The recidual liquid flowed down the tower in gradually lesening amounte and out the bottom through a IIquid log seal and into tho "bottom" produet drum. The rapor from the eperation wa condensed and fod into the "tops" receiver. The rates of these etreane wore meacured volumetrieally, and a run was not bogun wet11 tho produote flowed at a conetant rate as determined by inoremontal meacuremonte.

In eddition to the rate of flow wevuremosts, the tomperatures of the feed 21quor, the vapor, and the resldual liquid to bottome were obteined.

The steam to the jeoket of tho oolum was mintalned conotant by a Drown "Alr-o-line" preseure recorder and controller. The etean, after giving up its latent hoat, wa reasod through a brap at the base of the jeoket. The oondeneed etean leaving the trap was paceed through a sall condenser in order to liquefy any flanh vapor that might form. The rate 


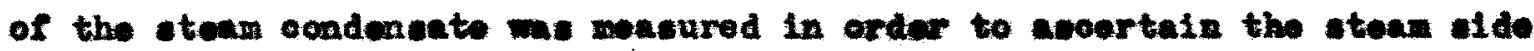
ooefrielents.

After the eonelueion of the hodt trancfer experiments neling vater alone, witures of ethanol and water were studied. These rune wore siallar In nature to the water rune with the axeoptlon that the foed as adjueted to the approximate deelrod oompostion. After the feed was dietilled, the "tope" and "botton" fratione wore andyzed for aleohol ooutent by the tandard prooedure of laboratory dintillation and refractive index moecurement. Thie eupplied all the necenenry information for the freotionation atrudies.

1. Callbration of Rotamoter

The rotaneter wat ealibrated in plece by atllisiag the following mothod. Weter wa pumped at a contant rotameter cotting, and the aotual

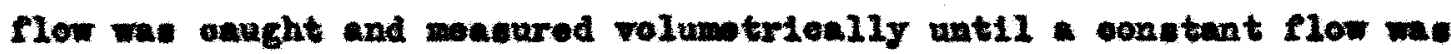

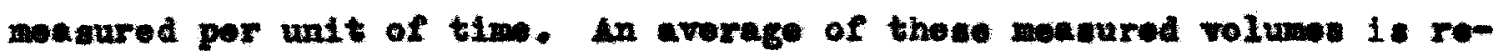
corded in Toble I as "notered flow - G.P.E". and is graphioully precentod In $\mathrm{Fig} \cdot \mathbf{8}$

Caleulations indiated that for food used in thio invectigation, deviatione aue to density wro nogligible. 
rable $I$. Rotamter Callbration

\begin{tabular}{|c|c|c|}
\hline Iun so. & $\begin{array}{c}\text { Rotanoter Recaling } \\
\text { G.P.H. }\end{array}$ & $\begin{array}{l}\text { Moterod now } \\
\text { G.P.H. }\end{array}$ \\
\hline 1 & 4.5 & 4.1 \\
\hline $\mathbf{z}$ & 11.3 & 11.6 \\
\hline 3 & 12.0 & 22.6 \\
\hline 4 & $14: 2$ & 15.8 \\
\hline 5 & 18.7? & 20.2 \\
\hline 6 & 10.1 & 20.6 \\
\hline 7 & 20.1 & $\mathbf{2 1 . 7}$ \\
\hline 8 & 20.2 & 21.8 \\
\hline 6 & 21.0 & 28.7 \\
\hline 10 & 84.8 & 86.6 \\
\hline 11 & 80.0 & 32.4 \\
\hline 12 & 39.0 & 42.1 \\
\hline $\mathbf{1 8}$ & 80.9 & 48.2 \\
\hline 24 & 43.8 & 46.8 \\
\hline 18 & 58.8 & 64.6 \\
\hline 16 & 68.5 & 70.7 \\
\hline 17 & 05.5 & 108.1 \\
\hline 18 & 95.9 & 108.6 \\
\hline 19 & 09.5 & 207.5 \\
\hline 20 & 108.0 & 111.2 \\
\hline
\end{tabular}




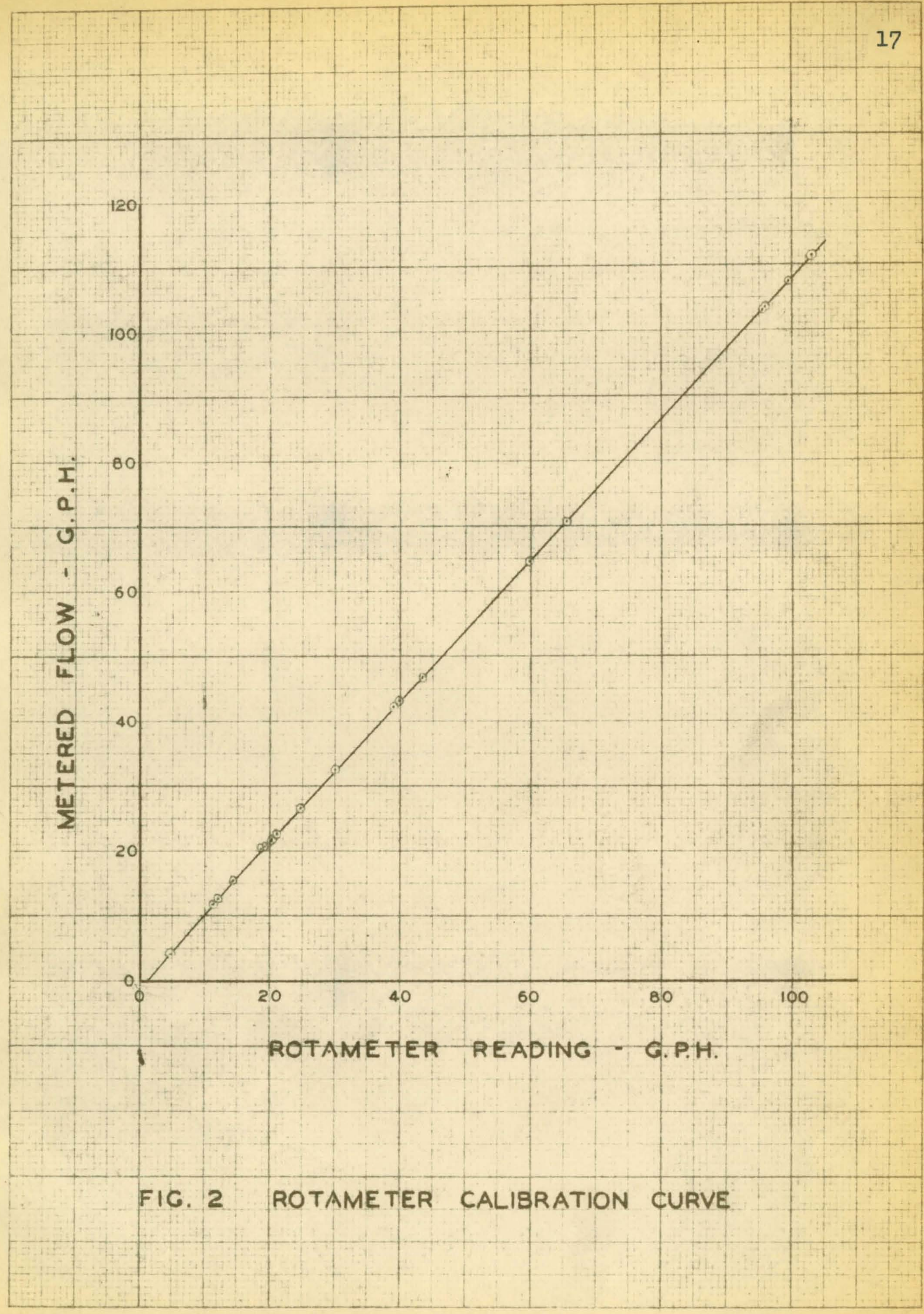


2. Extermal beat lovede from the colwm

The hot loses of the eolum wore cotermined by senling off the top and botton seotione of the colum to prevent undue comvetion on

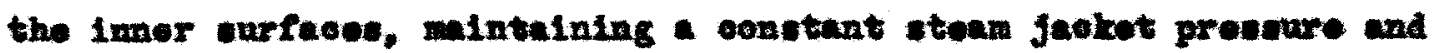
moveraring the rate of condentate from the otean jackot.

The condenente rate we oaloulated back to total heat noosecary to maintain colum temperature whout feod. These vilues oorrempondod to beat loween by rediation and eoveotion. Date are presontod in rable II and are correlated in PIg. 3.

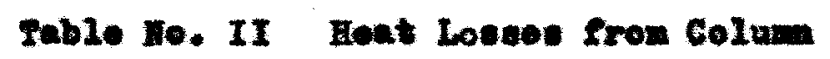

\begin{tabular}{|c|c|c|c|c|}
\hline Aun Ho. & & 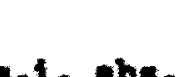 & Corresponglins & Loas in \\
\hline$B D-1$ & 1.86 & 16. 605 & 215.02 & $0,150.8$ \\
\hline 2 & 8.85 & 16.587 & 218.15 & $11,987.6$ \\
\hline $\mathbf{z}$ & 6.26 & 17.766 & 821.72 & $18,999.0$ \\
\hline 4 & 8.36 & 18.787 & 224.67 & $18,481.9$ \\
\hline 5 & 10.55 & 19.879 & 227.68 & 19.404 .7 \\
\hline 6 & 0.80 & 25.000 & 213.34 & $8,799.4$ \\
\hline 7 & 8.00 & 16.170 & 216.00 & $10,696.0$ \\
\hline 8 & 6.00 & 17.048 & 221.33 & $\mathbf{1 5}, 896.6$ \\
\hline$\bullet$ & 9.00 & 19.116 & 226.58 & $19,890.9$ \\
\hline 10 & 22.00 & 20.586 & 289.52 & $20,000.9$ \\
\hline
\end{tabular}




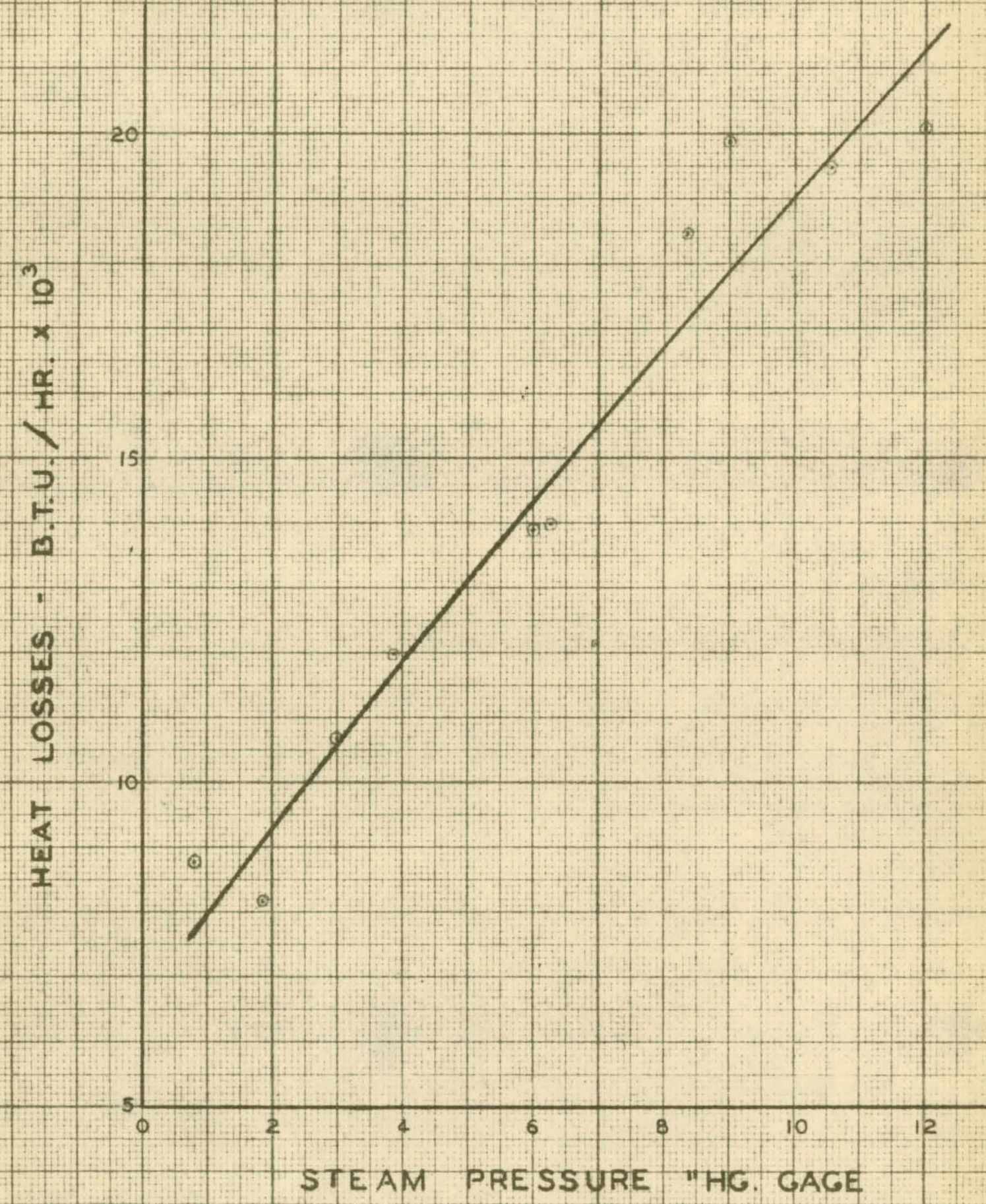

FIG. 3 hEAT LOSSES ON FILM TYPE STILL 


\section{Bxpertmontal Revult - Water Runs}

Complete data nore obtained for hat tranafer ealoulatione on the falling film ot121 as decoribed in the Exporinental Procedure and

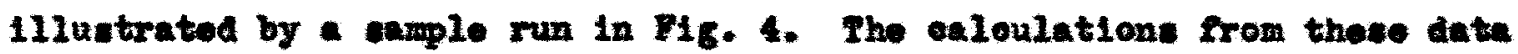
are explained in the samplo caloulationa ( rable IX), and are tabulated in Table $X$. A sumary of theee reaulte is presented in Table No. III. The value of the overall hout tranafer cooffletents are presonted for both trem aide and IIquid alde. These values were obtalned by coneidoring $\Delta t$ as the $\log$ mean differonoe betwean atwin jeoket tomportture and IIquid flim tompereture, area ae a oonstant relue obtained by wasuremont of the colwe and total hoat trancforred a the product of pound of etean exhausted and its tru Iatent hoat, 1. 1 . the differenco botweon tho opeeifio onthalpy of acturated vapor at the inlet preseure and that of the saturated bolling liquid at jealot preseure asmuming adiabatie oonditione sorose the inlet stem vive lose radiation losece.

The value of the overall Ilquid side coefrialent has the wame

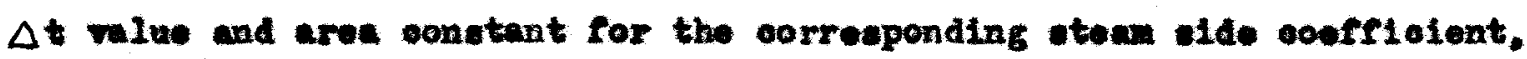
but the tatal hot tranaferred in this eave is the sumation of cencible hoat to the rapor. Iatont hout to the rapor, and seneible hoat to the bottoms. This coeffielent probably repreaente more nearly tho true heat tranefer coefflolent, at there is always a poselbillty of warying radiation loases due to atwoepherio disturbenese about the oolum, and the effect produesd by internittent trap eotion on the etean oondencate al sohare.

A oorrelation of data for host trancrer ooefriolents relating 
Operating Datas

\begin{tabular}{|c|c|}
\hline Rum No. & $w-45$ \\
\hline Dato & $4-17-45$ \\
\hline $\operatorname{Tm}$ & 6,52 P. E. \\
\hline Jeoket Steam Presenre & $6.57^{m}$ LE. \\
\hline Food romperature & $58.0^{\circ} \mathrm{C}$ \\
\hline Peod Rate & 42.9 G.P.H. \\
\hline Tope Produet Eate. & $178.000 / \mathrm{min}$ \\
\hline Botton Produot remporature & $98.0^{\circ} \mathrm{c}$ \\
\hline Dottom Produot Rate & $2586.0 \mathrm{oe} / \mathrm{min}$. \\
\hline Vepor Temperature & $100.0^{\circ} \mathrm{c}$ \\
\hline Itean Condensato Rate & $606.0 \mathrm{oc} / \mathrm{min}$ \\
\hline Roon romperature & $25.0^{\circ} \mathrm{c}$ \\
\hline Barowatrie Preeture & $756 \mathrm{me}$ \\
\hline
\end{tabular}

Reanrke! Oporatione ateady! good jaokot presoure oontrol

Mg. Ho. 4 - Serple Data Shoot 
Toble III - Sumary Data for Wator Rum

\begin{tabular}{|c|c|c|c|c|c|}
\hline $\begin{array}{l}\text { Rue } \\
\text { We. }\end{array}$ & $\begin{array}{c}\text { Foed } \\
\text { Rate } \\
\text { (G.P.E.) }\end{array}$ & $\begin{array}{c}\text { stana } \\
\text { Rate } \\
\left(1 / 4 x_{*}\right)\end{array}$ & $\begin{array}{c}\text { Jaeket } \\
\text { Prosenre } \\
\text { ("Ig.) }\end{array}$ & $\begin{array}{l}\text { cta. he } \\
\text { st. }{ }^{8}-\mathrm{p}\end{array}$ & $\begin{array}{l}\mathrm{stu} / \mathrm{h} \\
\mathrm{st} \mathrm{e}^{2} \mathrm{~s}\end{array}$ \\
\hline$w-1$ & 11.20 & 16.00 & 4.02 & 72.89 & 108.90 \\
\hline$w-2$ & 11.80 & 88.80 & 0.2 & 00.40 & 104.16 \\
\hline-8 & 21.4 & 82.10 & 9.2 & 108.60 & 120.18 \\
\hline 4 & 13.60 & 59.75 & 9.2 & 76.50 & 60.85 \\
\hline 5 & 12.60 & 58.66 & $: 9.2$ & 74.27 & 58.32 \\
\hline $7-6$ & 13.60 & tr. 48 & 0.26 & $\mathrm{re.16}$ & 86.60 \\
\hline $10-7$ & 4.10 & 57.81 & 9.1 & 43.96 & 48.45 \\
\hline$\pi-6$ & 3.20 & 57.77 & 9.1 & 66.00 & 77.08 \\
\hline$w-9$ & 22.26 & 56.86 & 9.0 & 74.32 & 66.28 \\
\hline$\overline{1}-20$ & 21.82 & 56.85 & 9.2 & 71.08 & 62.66 \\
\hline$x-21$ & 21.71 & 58.58 & 9.0 & 70.08 & 62.48 \\
\hline$w-12$ & 38.06 & 57.37 & 0.0 & $75: .08$ & 68.71 \\
\hline "x-18 & 32.40 & 57.64 & 9.1 & 69.83 & 68.40 \\
\hline-17 & 46.87 & 89.90 & 9.2 & 125.80 & 142.46 \\
\hline$n-28$ & 46.87 & 89.40 & 9.8 & 120.09 & 140.81 \\
\hline 10 & 46.76 & 68.69 & 9.2 & 121.38 & 134.42 \\
\hline 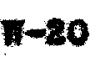 & 15.70 & 05.88 & 9.2 & 70.67 & 81.61 \\
\hline$H-21$ & 15.80 & 86.72 & 9.15 & 77.7 & 94.14 \\
\hline 11 & 27.48 & 88.26 & 9.4 & 108.72 & 114.65 \\
\hline$x-28$ & 26.78 & 84.61 & 0.05 & 105.02 & 221.45 \\
\hline & 26.24 & 86.09 & 9.4 & 105.05 & 128.87 \\
\hline
\end{tabular}


Tab2e III - sumary Data for Water Run (Conti)

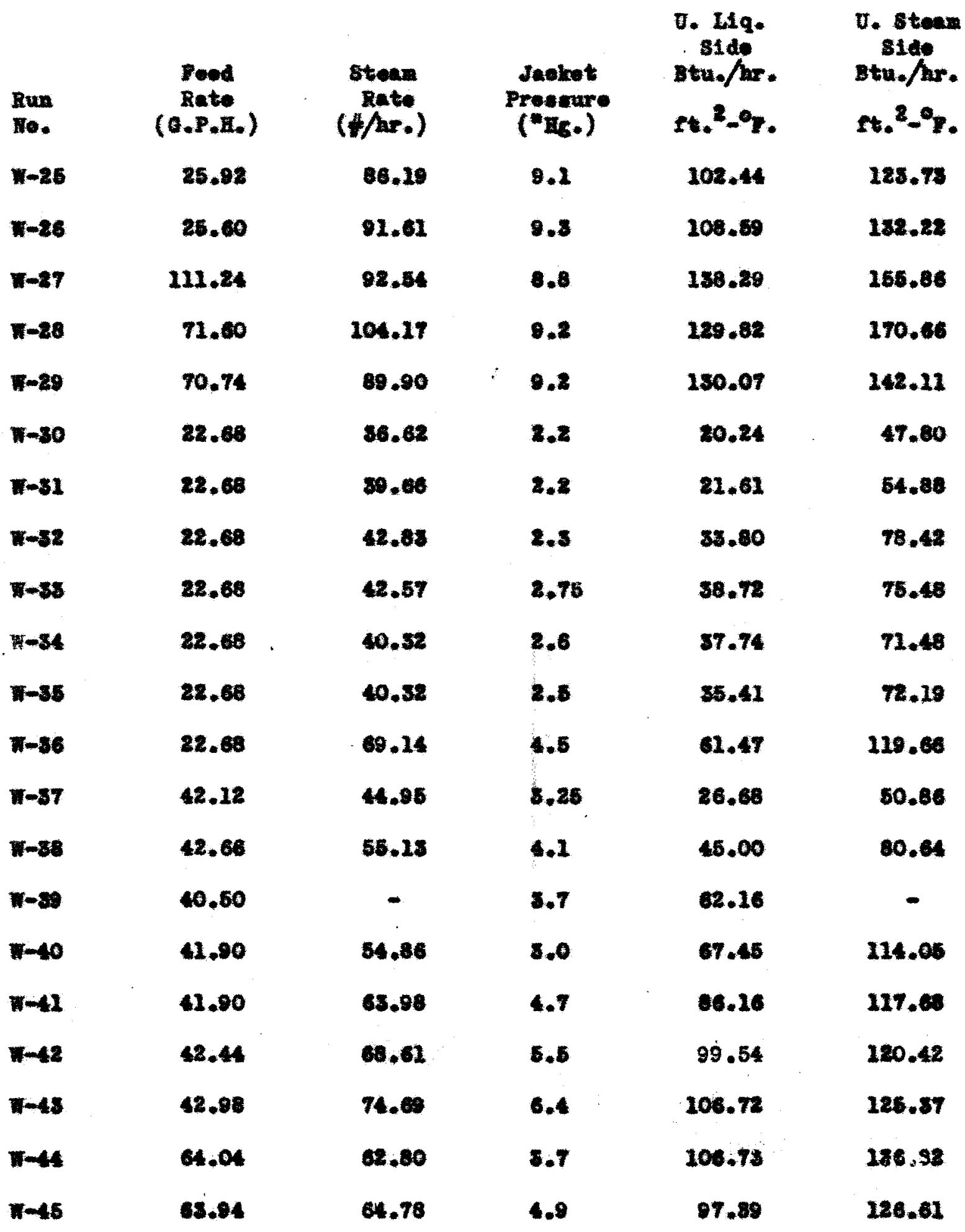


Table III - sumany Bata for Water Rune (Cont.)

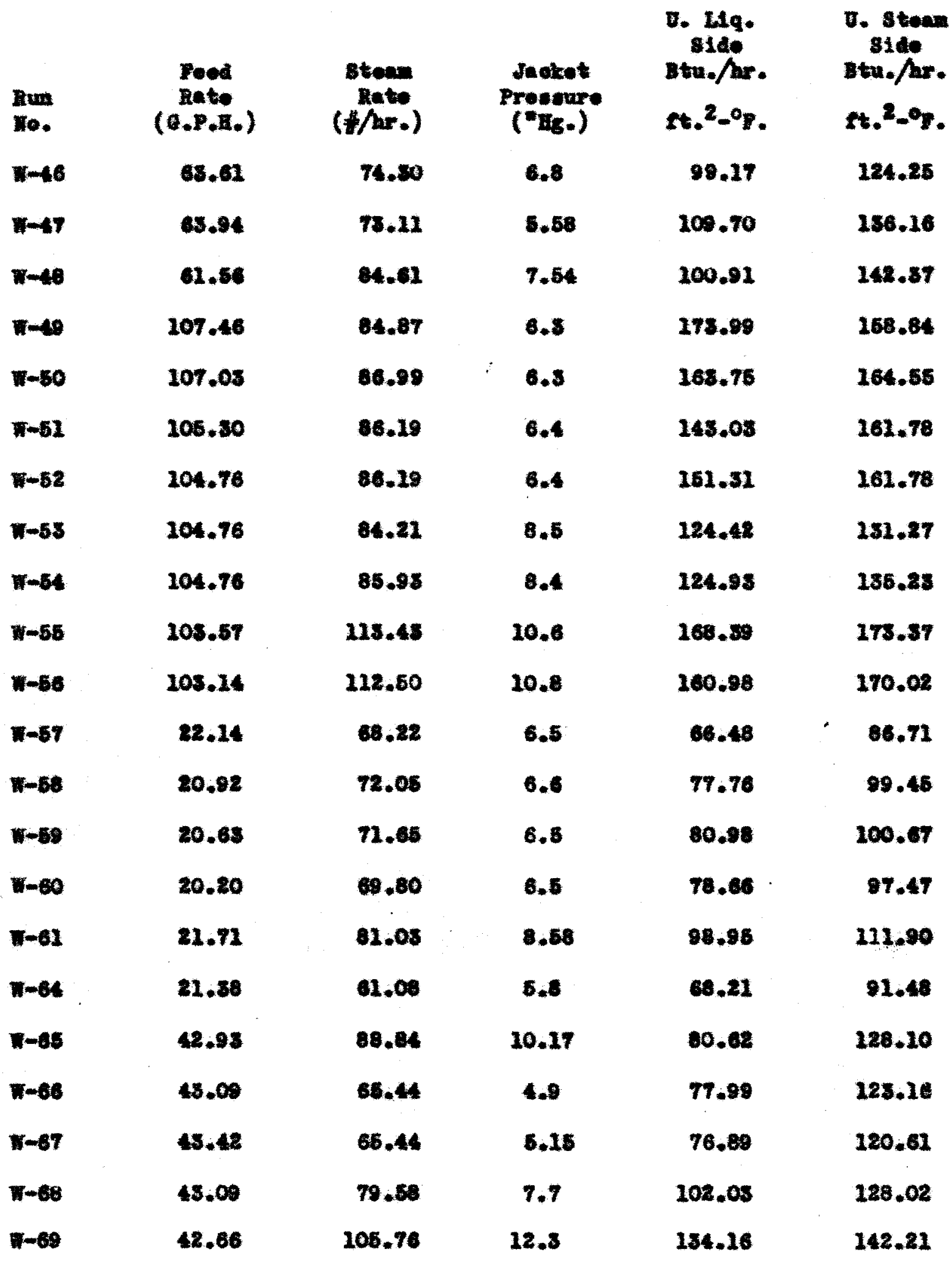


the overall coefrieients on the 11 quid olde with thone on tho otean elde 1. prosonted in Fic. 5. It is noted that the ourve is dieplaced from the $45^{\circ}$ 21ne alightly for the lowor values of the ovorall bat tranefor cooffiolent and to a woh lese extent at the higher vines of hout trancfor were obtalned. Horeover, the overall hoat trancfor ooffletent: from the liquid side entwalpies are presented in runotional relationghip to Iiquid read rate is 716. 6, whore avorage values of jeoket preacures at different feod rites are conmeded by the lines. 


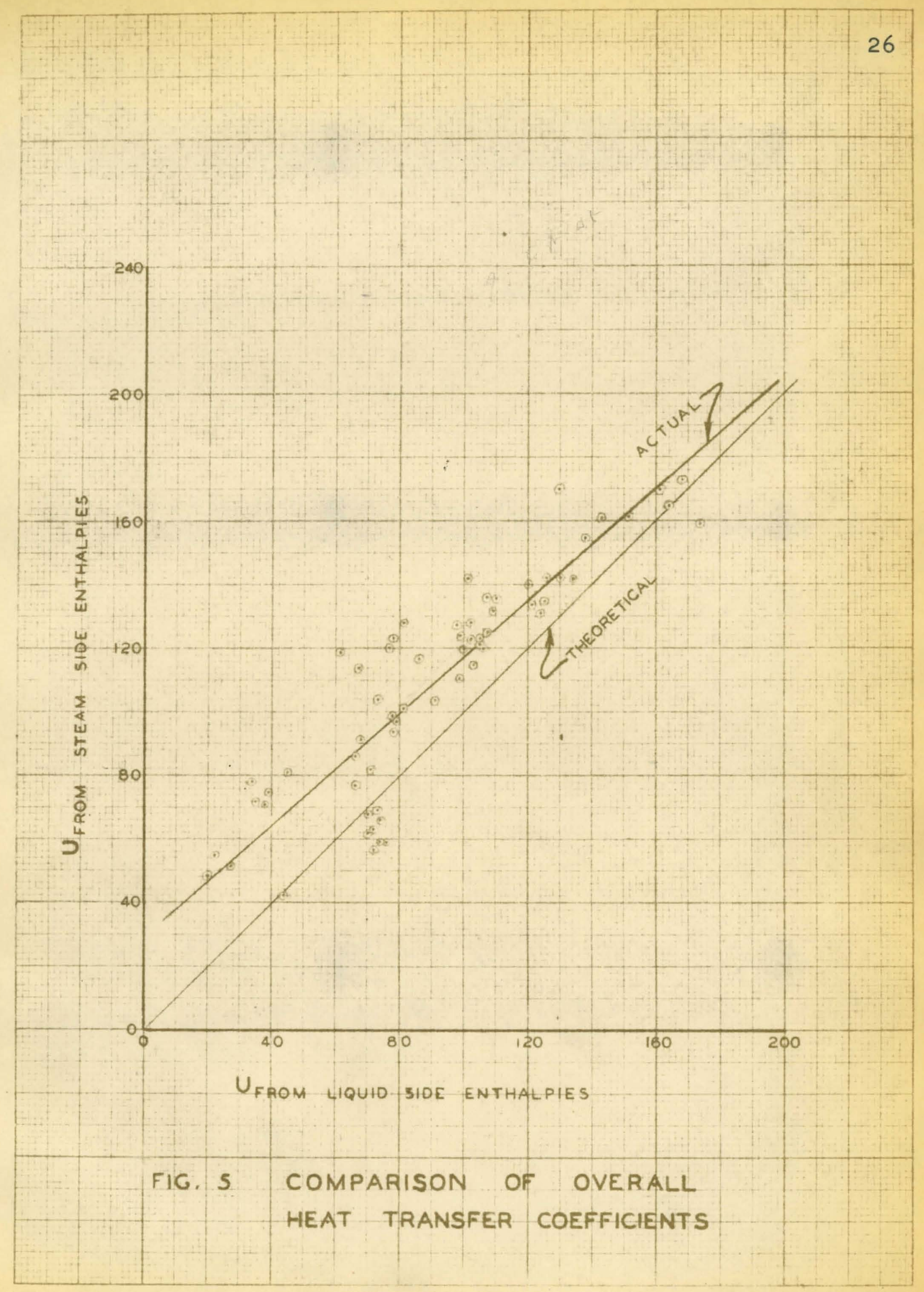




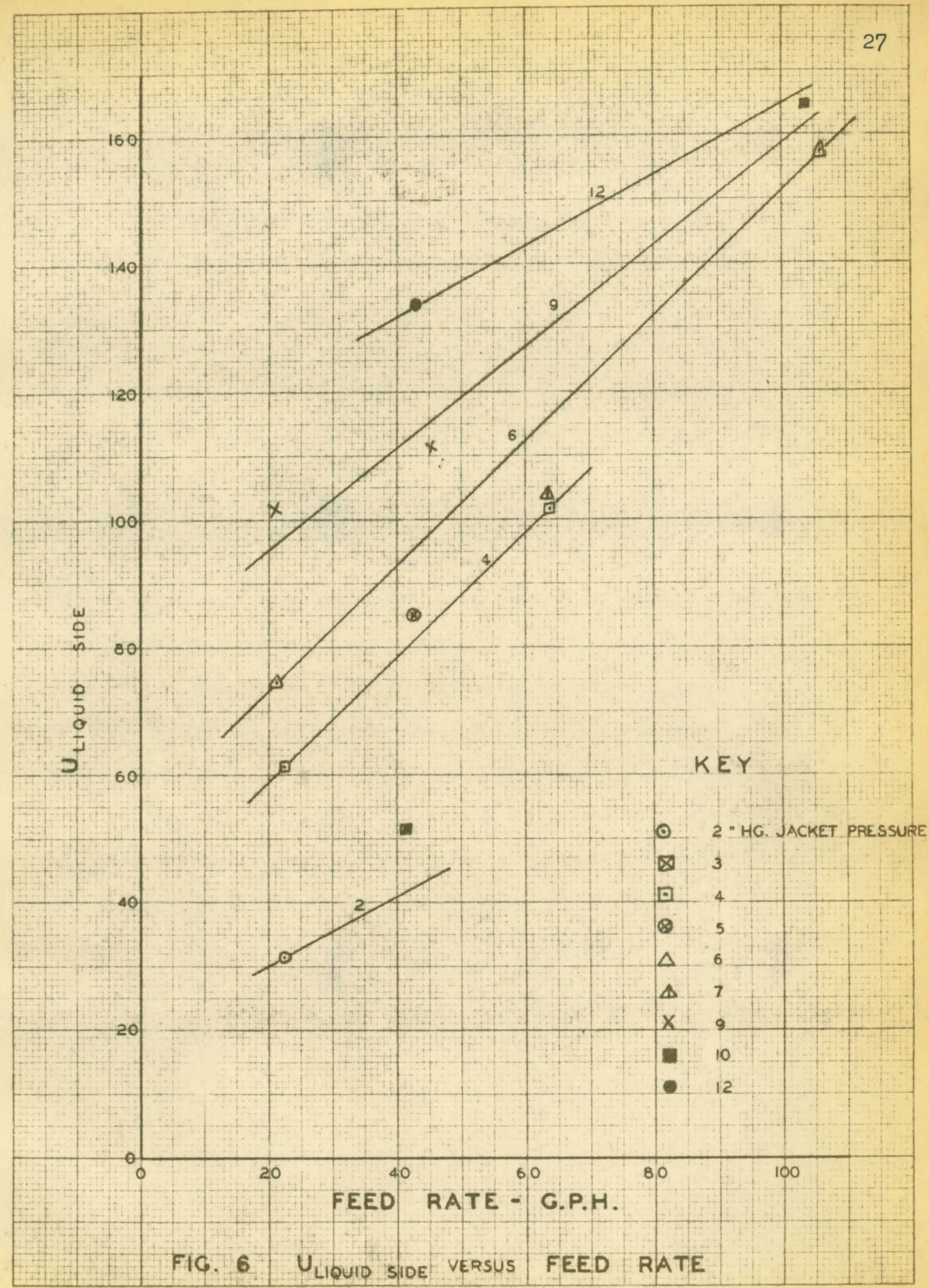


Exporimontil Rowits - Mloohol Rune

The date of the aleohol runs, becides inoluding that for hout tranafor relatione, centained noveseary data for froblontion studiew. The provodure was to $m i x$ othenol and wator to approxtante

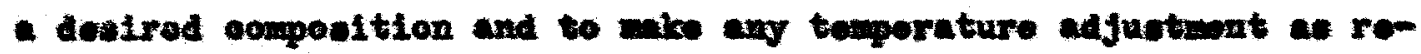
quired. Foed wa then Introduesd to the colum and walntainod eanatent. Product eampleo nore tabon until volungtrie rateo wore constant. Spot uaples wore taken arter this polnt and lator mixed for average analyeos. Aloohol eorpositions wore obtained by a stendard Iaboretery proesdure of Inboratory fraetionntion and refractomatio meneuromot. The latest edition of the Hegnor rablev was oonoulted fer converelon of refraotomoter readinge to pereant aloehel by volume. The data for hoat trancer on the aleobol atxtures are prouented in 716. 7. This figure show the relatien of everall hoat tranerer coorfioleate to the aloohol roed rate of the colum. The resulte of the fractionation are presented in rable $\mathrm{I}$.

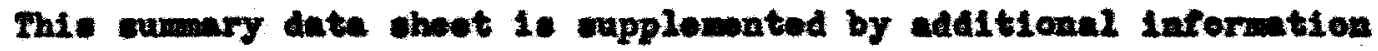
conoerning these runo and is inoludod in the Appondix (Table $X$ ). 


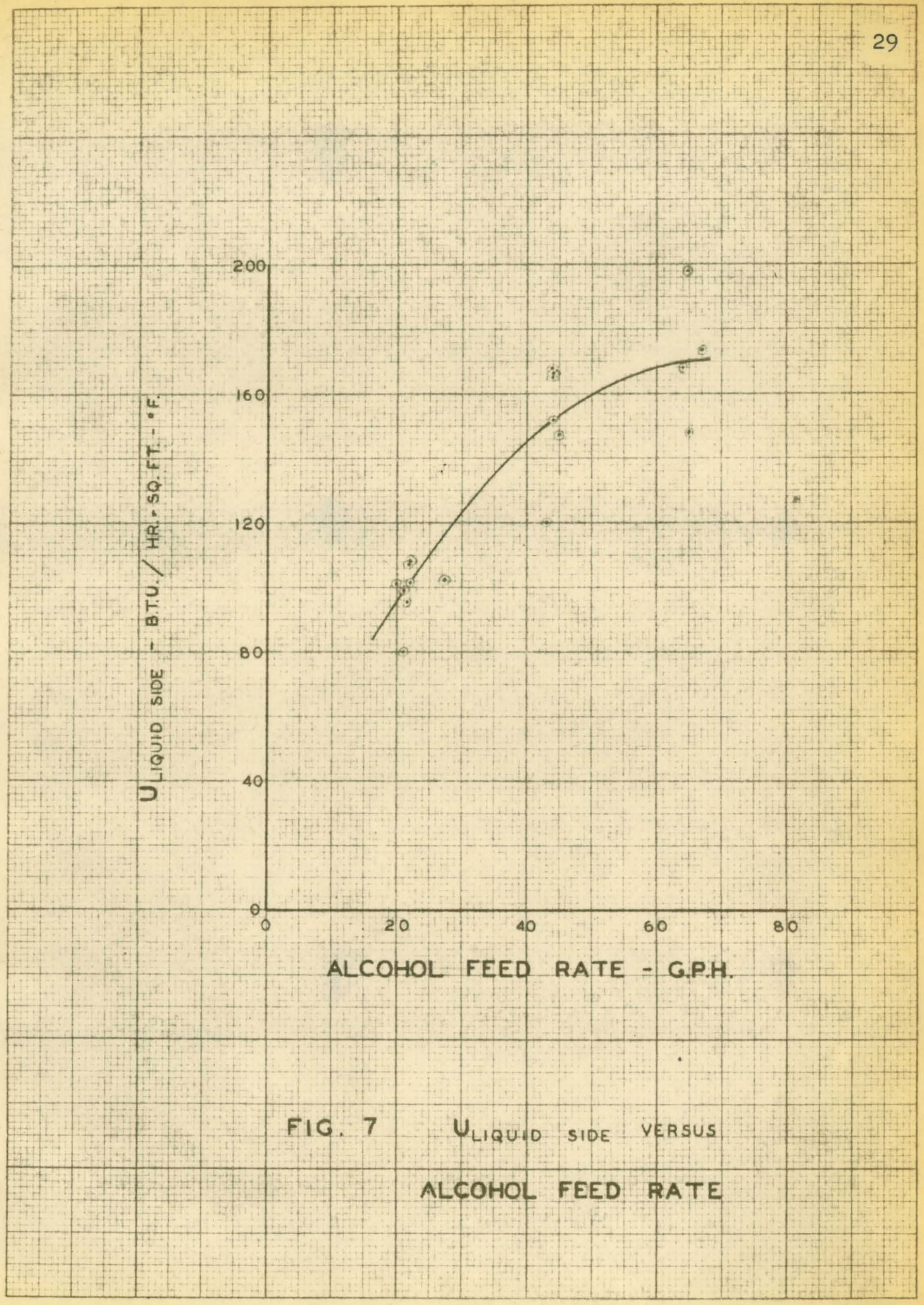


Table IV - Sumary Data for Bthanol Rum

Liquid side coefriolente

\begin{tabular}{|c|c|c|c|c|c|}
\hline $\begin{array}{l}\text { Ren } \\
\text { no. }\end{array}$ & $\begin{array}{c}\text { Abs. } \\
\text { Prosevere } \\
\text { (p.e.t. }\end{array}$ & $\begin{array}{c}\text { Plew } \\
\text { Rate } \\
\text { (a.P.R.) }\end{array}$ & $\begin{array}{c}\text { rotal } \\
\text { Eont } \\
\text { (Btu./ar.) }\end{array}$ & $\begin{array}{l}2 \times 100 \\
0 .\end{array}$ & $\stackrel{\text { vg. }}{\text { ug. }}$ \\
\hline$M-1$ & 18.14 & 27.50 & 52510.68 & 4.0 & 108.00 \\
\hline$\mu-2$ & 18.04 & 21.92 & 66509.50 & 10.0 & 201.50 \\
\hline$M-5$ & 17.98 & 46.00 & 70582.67 & 41.1 & 148.86 \\
\hline$M-4$ & 17.99 & 66.01 & 81457.67 & 10.1 & $17 \% .7$ \\
\hline$\mu-6$ & 18.87 & 21.28 & 64845.12 & B6.0 & 99.06 \\
\hline$\Lambda-6$ & 19.06 & 45.65 & 79577.68 & 4.7 & 152.29 \\
\hline$\Lambda-9$ & 19.24 & 64.42 & 88749.62 & 45.8 & 167.50 \\
\hline$M-B$ & 17.89 & 19.82 & 54804.11 & 46.8 & 101.25 \\
\hline $\mathbf{M}-\mathbf{0}$ & 17.64 & 48.85 & 77808.78 & 40.1 & 164.92 \\
\hline$M-10$ & 18.16 & 22.44 & 55468.68 & 50.0 & 80.48 \\
\hline$M-11$ & 18.14 & 42.77 & 70608.36 & 60.6 & 119.58 \\
\hline$M-12$ & 18.10 & 64.58 & 85278.15 & 49.2 & 148.27 \\
\hline $4-18$ & 17.70 & 21.38 & 67452.85 & 60.4 & 95.50 \\
\hline$M-14$ & 17.78 & 4.28 & 97998.16 & 50.6 & 165.67 \\
\hline$M-16$ & 10.12 & 21.65 & 75878.42 & 60.6 & 107.10 \\
\hline $4-26$ & 18.24 & 21.92 & 63857.75 & 60.2 & 207.85 \\
\hline$M-17$ & 28.11 & 48.60 & 64587.90 & 48.0 & 188.28 \\
\hline$M-18$ & 18.06 & 64.75 & 89644.20 & 48.0 & 108.28 \\
\hline
\end{tabular}


Table IV - sumary Date for Dthenel Rune Coupoertion Data

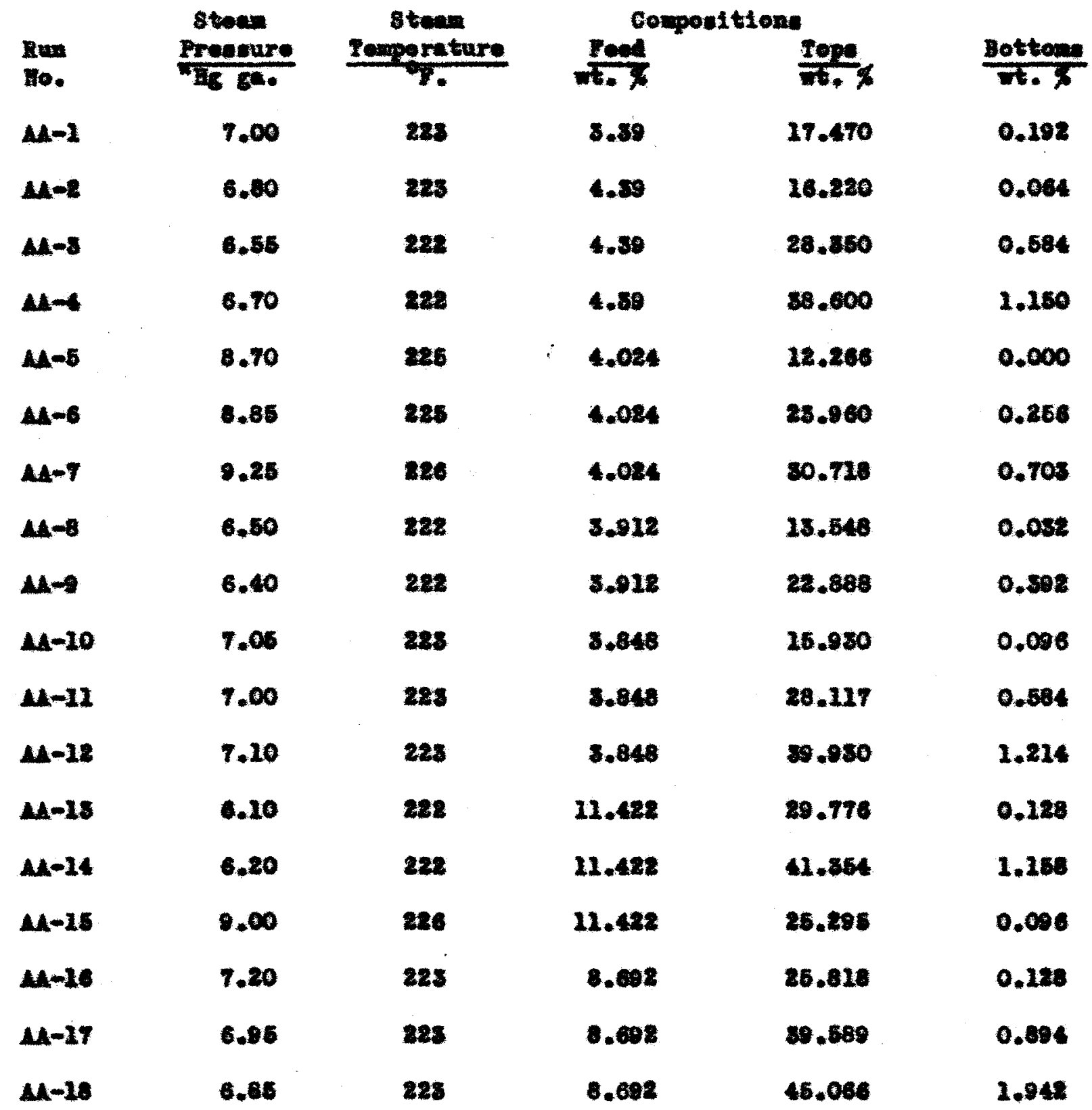


coneturros $\mathbf{x}$

A developint of thooretion relations for film type dietilletion by a diroot approain appoared to be axtromely complieatod, therefore, an indireot wothod of attack wa ut111sod. Provious inveotigatore (9)

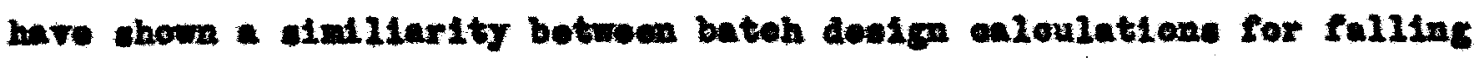
112 botlare and exporimontally dotorinod date. Their work acoumod a IImtation to substanees whose raper-11quid equilibrium followed Reonlt'. Law eloedy. This linttation on be firewarented by the ued of somo Agobrale oquation to relate the olleulated ralues to the aotual values. In the dewlepment of this eorrelation, Reyleigh' Equation for aff ratial distillation should apply sino by definition of this provose, the compontion of the Ilquid ehenge eontinualiy during the dietillation. Froa the Rayleigh Equation

$$
\ln \frac{B}{F}=\int_{x_{F}}^{x_{B}} \frac{d x}{y-x}
$$

whore

$$
\begin{aligned}
& \text { D = Eole (1bo.) of strippod naterial. } \\
& Y=\text { Wole (1bs.) of tood material, }
\end{aligned}
$$

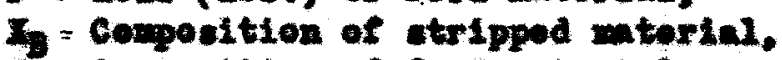

$$
\begin{aligned}
& x_{7}=\text { cempostien of foed utorial. }
\end{aligned}
$$

there are ae kewne, B. F. IFt thorefore It is poesible to find $X_{B}$ by graphieal integration. This proesdure ylelde a oaloulated componition of tho stripped material from whioh the funetion of the cotud exporinental

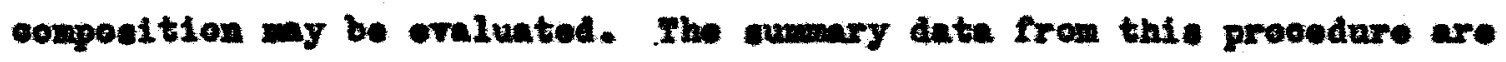
prosented in rable $\nabla$. 
roble V - Caloulated Compouttione by Ravleigh Froedure

\begin{tabular}{|c|c|c|c|}
\hline $\begin{array}{l}\text { Rum } \\
\text { No. }\end{array}$ & 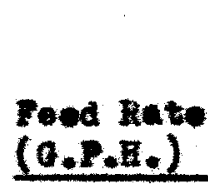 & $\begin{array}{c}\text { Bottom } \\
\text { Couponitioa } \\
(\text { t. } .5) \\
\end{array}$ & $\begin{array}{l}\text { Caloulated } \\
\text { Bottom } \\
\text { Composition } \\
(\text { wt. } 1)\end{array}$ \\
\hline $\begin{array}{l}M-1 \\
M A-2 \\
M A-3 \\
M-4 \\
M-6 \\
M-6 \\
M-7 \\
M-6 \\
M-9 \\
M-10 \\
M-11 \\
M-12 \\
M-25 \\
M-14 \\
M-16 \\
M-16 \\
M-17 \\
M-13\end{array}$ & $\begin{array}{l}27.30 \\
21.92 \\
45.09 \\
66.91 \\
21.28 \\
43.05 \\
64.42 \\
19.02 \\
48.86 \\
21.44 \\
42.77 \\
94.68 \\
21.88 \\
44.28 \\
21.68 \\
21.02 \\
43.69 \\
64.75\end{array}$ & $\begin{array}{l}0.192 \\
0.064 \\
0.584 \\
1.150 \\
0.000 \\
0.256 \\
0.708 \\
0.052 \\
0.092 \\
0.096 \\
0.584 \\
1.214 \\
0.128 \\
1.168 \\
0.096 \\
0.128 \\
0.694 \\
1.048\end{array}$ & $\begin{array}{l}0.462 \\
0.271 \\
1.447 \\
2.184 \\
0.000 \\
0.850 \\
1.675 \\
0.280 \\
1.047 \\
0.180 \\
1.386 \\
2.288 \\
0.000 \\
2.168 \\
0.000 \\
0.226 \\
1.685 \\
3.124\end{array}$ \\
\hline
\end{tabular}

The relation between the cetual and ealoulated Bottona Cosposition my be expresed by the approximate equation:

$$
x_{\text {enloulatad }}=(1.96)\left(x_{\text {aotanal }}\right)^{0.7405}
$$

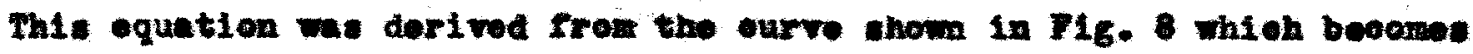
- tralght line when plotted on log-log voordinates es presented in 16. 9. 


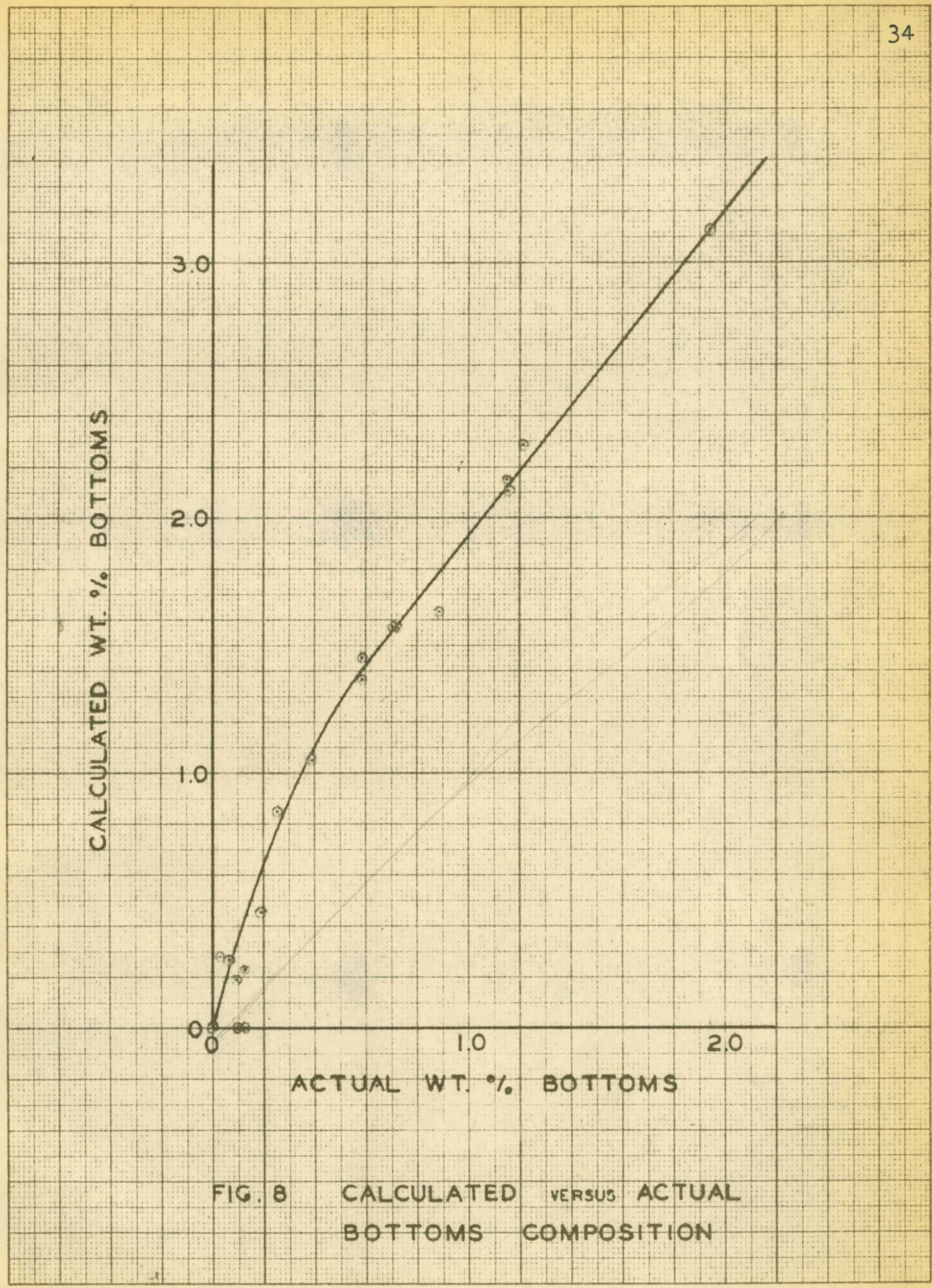




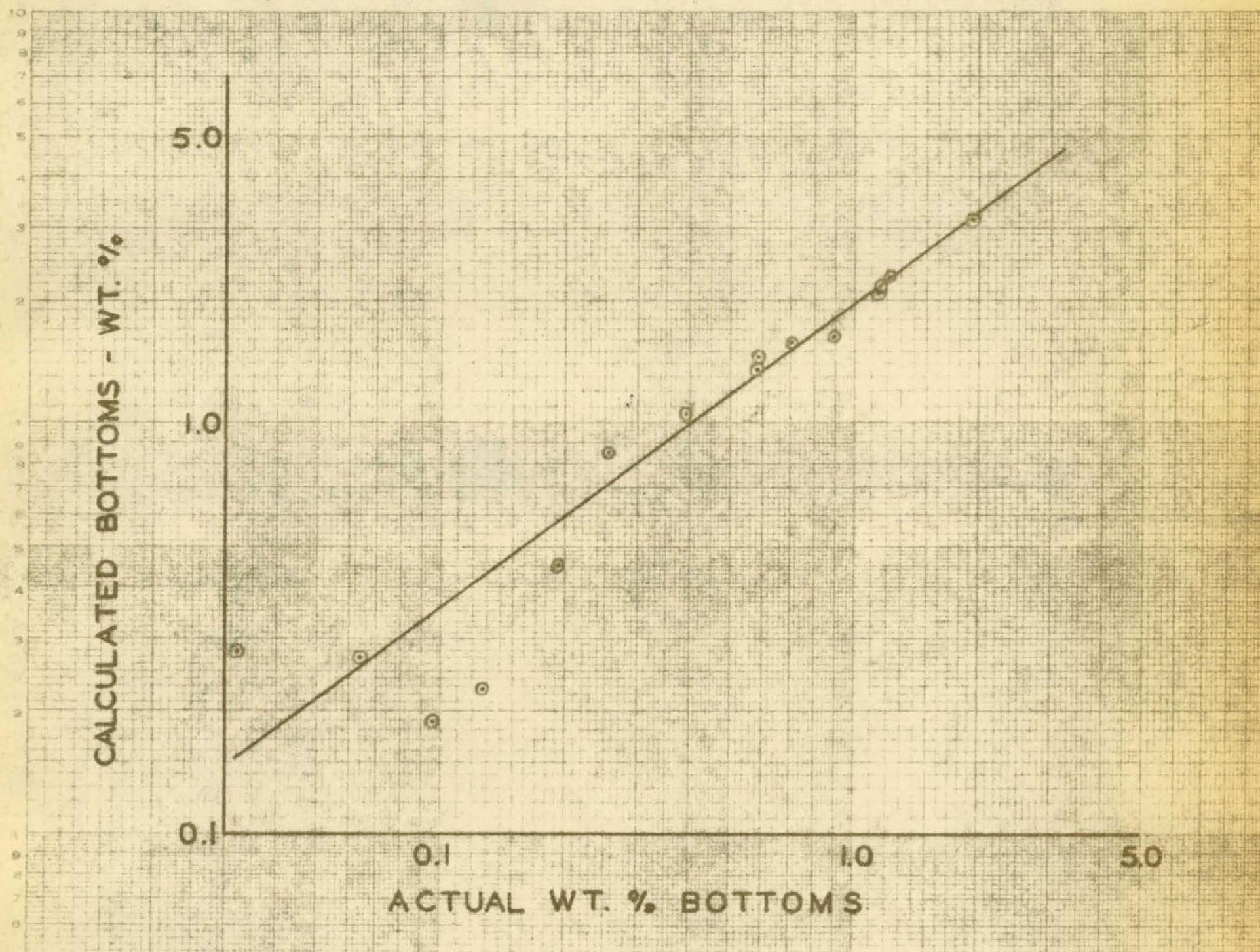

FIC. 9 CALCULATED VERSUS ACTUAL BOTTOMS COMPOSITION 
CORDELTION II

4 cooend corrolation wa attompted on the apeumption of a conetant rate of hoat trancfor from stean to falling 11quid, and with tho

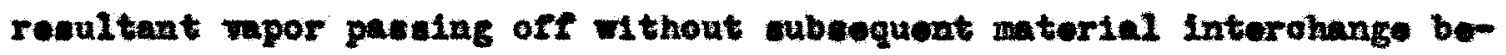
tweon mpor and 11quid.

This anounption leads to onleuletion of rapor and liquid rates throughout the ooluma and therefore value for the elope of the equilibrium eperating 11ne.

Th1s proeddure falled, as the blope of the operating line we not a continoously inereaning funotion from food atranoe to liquid exhaveting poestion as postulated. It appoared that a point of incleotion

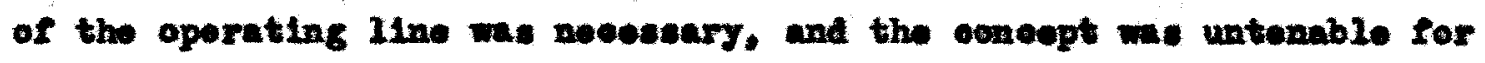
this reamen. 
CORARLATE III

Inmber of Thoorotieal Plates at Total Reflux

4lthough this mothod is theorotionlly unound for roporting Anta for distillation oporetiens in wioh thore is no cxternal reflux, it does present oharaeteriotio of dietillation equipent whioh have com rmetional ralus.

The date from this proopdure are:

Table VI - Huber of Thoorotian Platos at Total Roflux

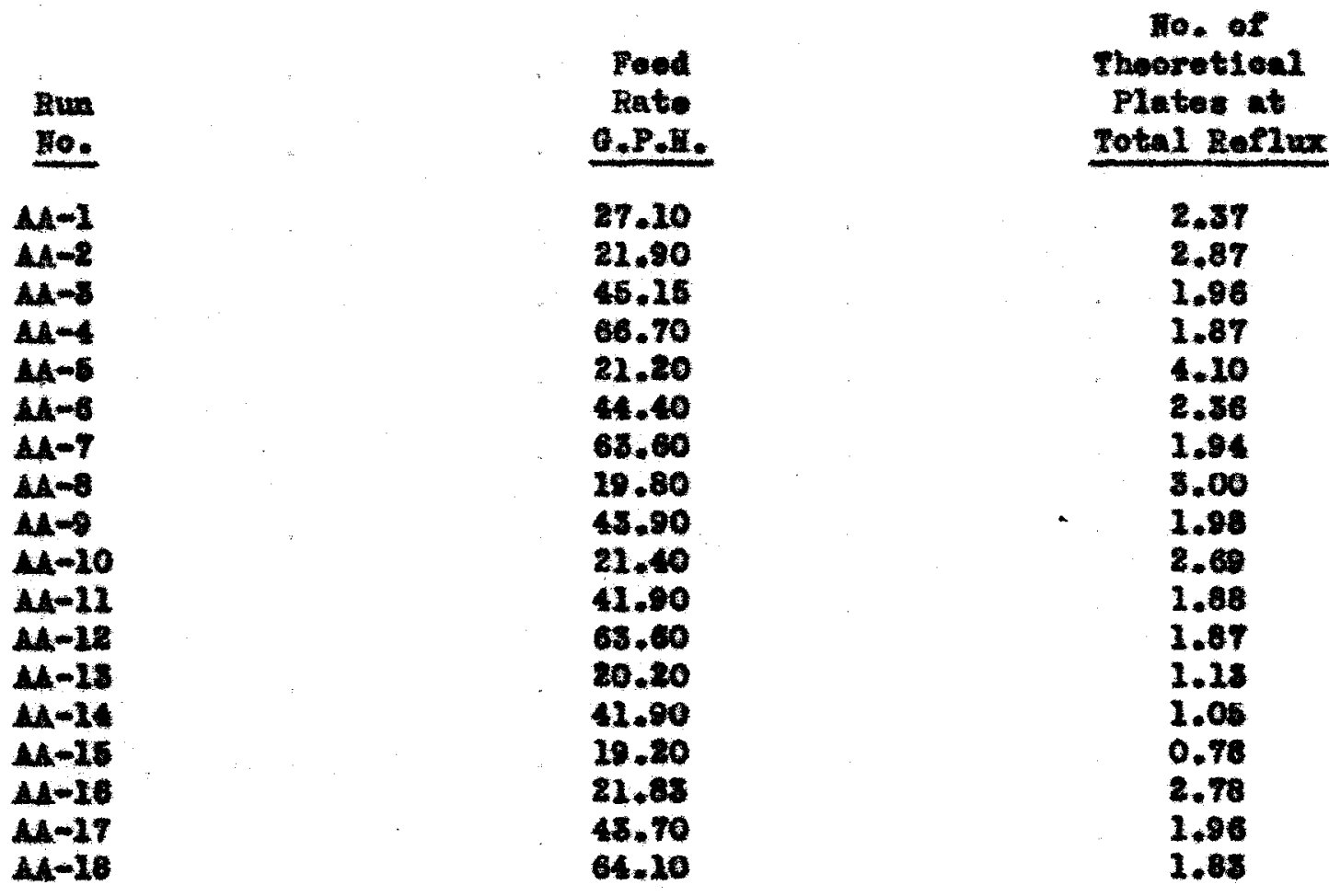

In aranination of the dete indionted the oritieal importanoe of rood rate whioh he been previeusly pointed out by suroniee and Purnas (y). 


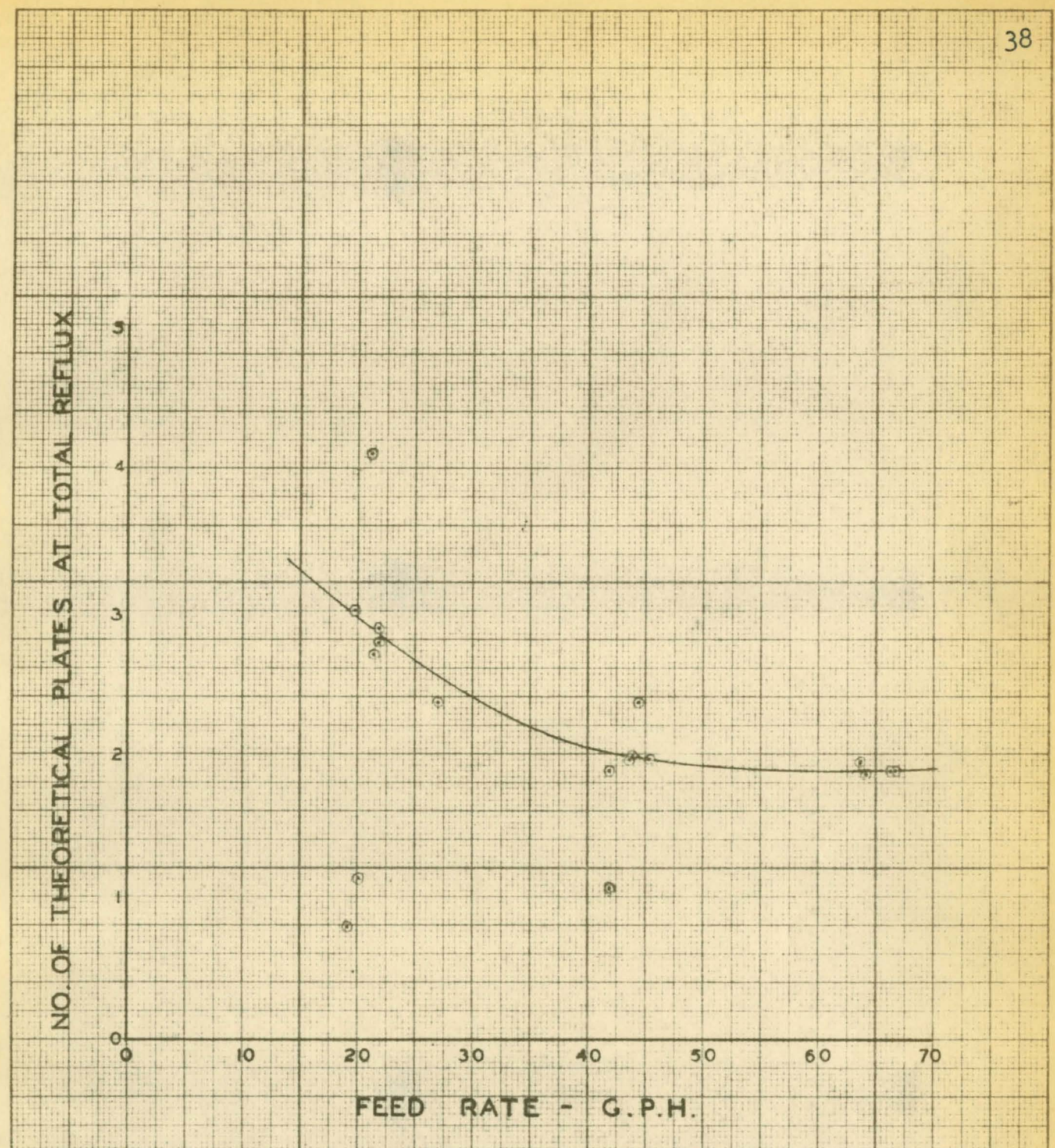

FIG. 10 NO. OF THEORETICAL PLATES AT TOTAL REFLUX VERSUS FEED RATE 
sonntur And colcLusrons 
(1) Hoat tranefor date on the film typo otill indieate falriy normal overall hout tranefor coeffieionts. The omly data avaliable on a unt of compuruble alse is that prosented by Bage in the

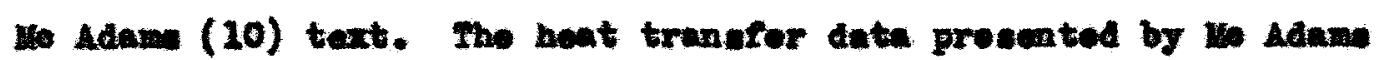
(20) and thow in F18. 11, wore obtalnod on alwa of 2.5 inehes in dlawoter and 2.0 foet high. Their data are for film flow in a vertieal tube hoter, without aperiention. Tho Fuevelt Bquation would Indi onte that the trancfer eocfelelent 1. Invereely proportional to the tube length. The 15.66 foet long tube uned in this inventigation is oonviderably longer than that of Bays, and therefere the lewer eoffielente are gual1tatively predietable. Data shown in the authort ourve are only for rum in whioh little or no raporiation oevurred. (2) Higher valuen of the overall hout trander eoffiolent wore obtained in the aloohol rums who eompered with tho date of the

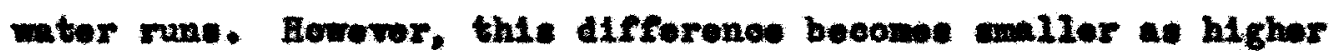
feed rates are utillsod.

(3) In aleohol-water axture of apprextmely $7 \%$ by wolum oan be otrigped eomplotely by proper balenos of rood rate and peroent raporlutation.

(4) The highor the coneontration of aleohol in the roed uixture, the greater is the ontralnagnt and the more aifficult it is to denloohollse the food in flin type oolwen.

(5) Change in flow rate bas a very noticeable effoet on frationtion

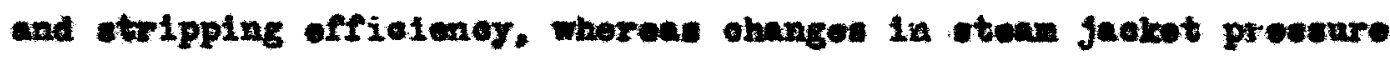


SYMBOLS:

CURVE A: MCADAMS (10)

CURVE B: DATA OF AUTHOR

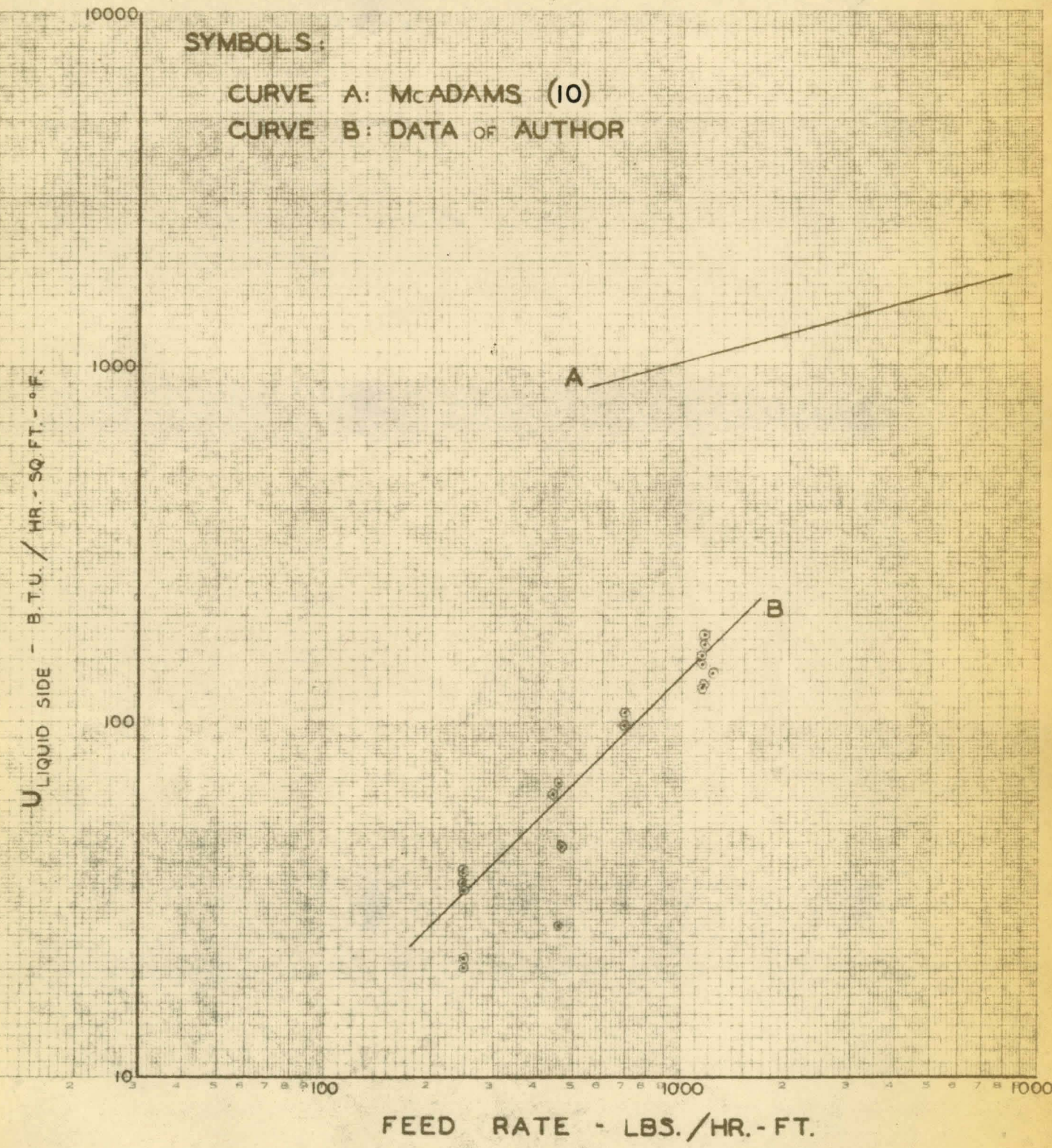

FIG. II COMPARISON OF FALLING FILM HEATERS 
or food tempereture mave apparently 11 ttle effect.

(6) The higher the eleohol coneentration, the lower the number of thoorotioal plator.

(7) The number of theoretienl plates is an Inveree funotion of the foed rate.

(8) 4 modifleation of the Rayleigh Equation probably afforde the bot mothod of evaluating filn atill oporation. 
LI TRATUE CITE 


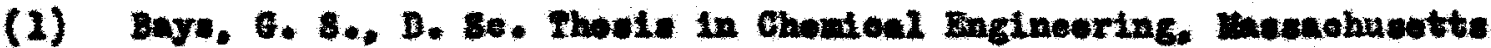
Inotitute of Teehnoless. 1936.

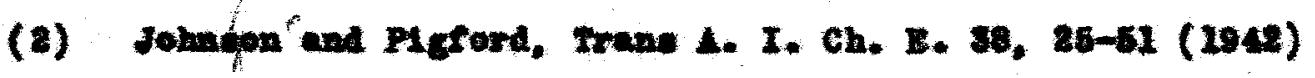

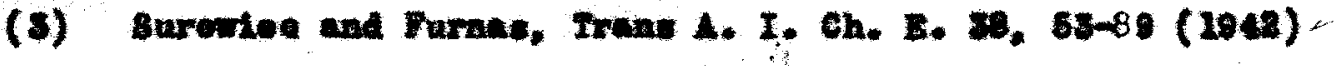

(4) Woatharer, J, H., I. I. C, 34, 216 (2042)

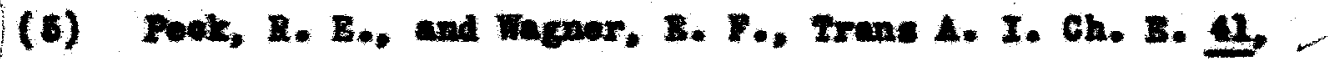
$787(1048)$

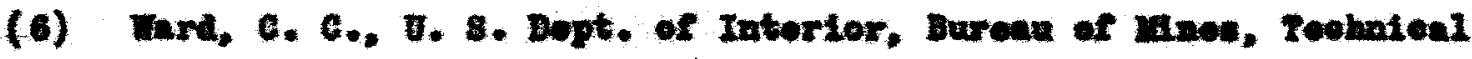
Paper no. 600.

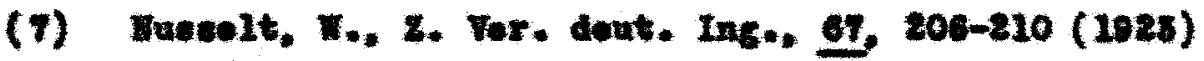

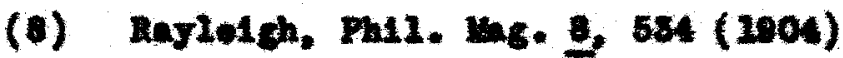

(9) Copolend and Hoodfleld, Frivate Comanioation Juwe, 1846.

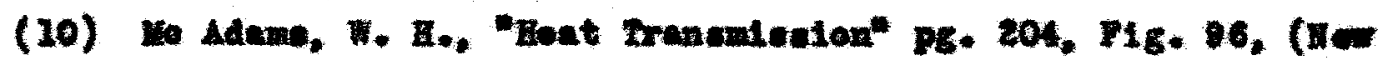
Tort, 1042) 
APPBDTX 


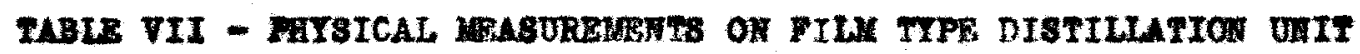

FIL STIL

Inoide dianetor

Helght

Wall thielanoas

Notal110 ourtase

Eloat tranefor arex

TAPOR HEN

Inolde diamotor

Volve

ESTRATIEST SEPARATOR

Folvan

comprastax

Tabe dianoter

Tube length

Numbar of tubes

Iotal compention

Hoat transfor ourface

Type ayetem

TBED TAN

Capaesty

TOPS RECEIVE

Capaotty
$215 / 10^{n}$

15* $6 / 4^{n}$

$8 / 8 n^{*}$

coppor

$11.69 \mathrm{eq} . \mathrm{ft}$

$113 / 4$

1, 290 ou. in.

1, 156 ou, in.

$7 / 0^{*}$

$691 / 2^{n}$

14.0

Copper

18.47 eq. $2 t$.

Water in obel1

$50.0 \mathrm{gallow}$

56.0 gallona 


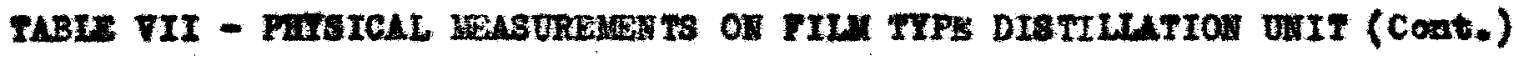

BOrTON RBCEIVER

Ceparetty

ROTALTERR

Range

Bp. gr. opeolfteation
65.0 satione

$\sin$ s. p. h.

1.06 
TABLS VIII - SUMARY COMPARISON OF IBDUSTRIAL BEER STRIPPINO EQUIPUEAT

\section{SIUPHCITI 으 DESIOII}

\begin{tabular}{|c|c|c|c|c|c|c|c|c|c|c|}
\hline UNIZ & $\begin{array}{l}\text { Col- } \\
\text { STREG- } \\
\text { rIOH } \\
\end{array}$ & $\begin{array}{c}\text { urix- } \\
\text { re- } \\
\text { rusce }\end{array}$ & $\begin{array}{c}\text { Prgissuns } \\
\text { DROP } \\
\end{array}$ & $\begin{array}{l}\text { EFTIC- } \\
\text { IBHCX } \\
\end{array}$ & CAPACIR & $\begin{array}{c}\text { LIQDOR } \\
\text { HoLD- } \\
\text { OP } \\
\end{array}$ & $\begin{array}{c}\text { mrand - } \\
\text { Hars } \\
\end{array}$ & $\begin{array}{l}\text { rovLIMO } \\
\text { TBNDENCY }\end{array}$ & $\begin{array}{r}\text { EASE or } \\
\text { cLEAYIMO } \\
\end{array}$ & $\cos x$ \\
\hline $\begin{array}{l}\text { 810ve } \\
\text { Plate }\end{array}$ & Poor & Poor & $\begin{array}{l}\text { rafirly } \\
\text { BIgh }\end{array}$ & High & High & High & Modium & Low & Fair & Bich \\
\hline Bubble & Poor & Poor & $\begin{array}{l}\text { Voty } \\
\text { Bish }\end{array}$ & High & Woderate & $\begin{array}{l}\text { Vory } \\
\text { High }\end{array}$ & H1gh & High & Poor & $\mathbf{H 1} \mathbf{g h}$ \\
\hline $\begin{array}{l}\text { Paoked } \\
\text { Tower }\end{array}$ & Pair & Pair & $\begin{array}{l}\text { Voty } \\
\text { B1th }\end{array}$ & Good & Hoderato & Elgh & $\begin{array}{l}\text { Vory } \\
\text { iligh }\end{array}$ & HAgh & Poor & Hodiun \\
\hline $\begin{array}{l}\text { Bateh } \\
8 t 111\end{array}$ & Fats & Falr & $20 \%$ & Low & Low & 20w & High & Wodernte & rair & Low \\
\hline $\begin{array}{l}\text { 8pray } \\
\text { 8ti11 }\end{array}$ & Poor & Poor & Low & Low & $\begin{array}{l}\text { Vory } \\
\text { Low }\end{array}$ & H1gh & Fich & Low & 0004 & $\begin{array}{l}\text { Jory } \\
\text { High }\end{array}$ \\
\hline $\begin{array}{l}\text { Casonde } \\
\text { st111 }\end{array}$ & oood & cood & $\begin{array}{l}\text { Fairly } \\
\text { Low }\end{array}$ & High & Kodorate & High & Lor & Low & $000 d$ & Lon \\
\hline 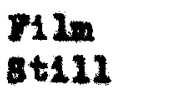 & Cood & Good & $\begin{array}{l}\text { Extromoly } \\
\text { Low }\end{array}$ & Ralr & Low & . Tory & Low & Low & $\begin{array}{l}\text { Exoe12- } \\
\text { ent }\end{array}$ & Low \\
\hline
\end{tabular}

1 Comerelally uneatiefaotory as beor oolumes. 
Table IX - Sample Calculatione

\section{(1) Heat Losses from Colvin}

Bun SE-7

Data: Jacket Presaures 3.0" $\mathrm{H}_{5} .=16.169$ pal abs.

Condensate Collected: $82 \mathrm{cc} . / \mathrm{min}$. arerage.

The true Latent Heat is the differenee between the lhalpy of the Satnrated Vapor (at the Iine preasure) and the apecifie entinalpy of the Baturated Bolling Liquid, herefore:

$$
\Delta \text { V vapor }-\Delta H \text { Hiqu }=\text { True Latent Heat }
$$

1171.9 Btu./1b. -184.95 Btu./1b. $=986.95$ Btu./1 b.

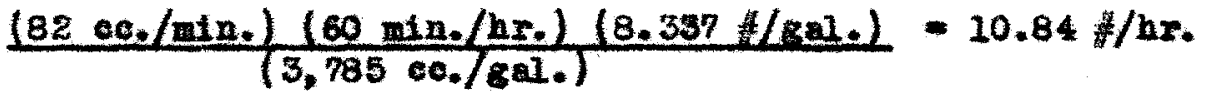

$(10.84 \mathrm{H} / \mathrm{hr}$. $)\left(986.95 \mathrm{Btu} / 1 \mathrm{~b}_{*}\right)=10,698.9 \mathrm{Btu} . / \mathrm{hr}$.

(2) Orerall Heat iransfor Coefrlei ente

(a) Based on Steam Side Inthalpies: Run 7:

Data: Condensate collected: 435 ce./nin.

read Temperature: $138.2^{\circ} \mathrm{F}$.

Bottome Teaperature: $162.5^{\circ}$.

Steen Teaperaturet $225.7^{\circ}$.

$\frac{(435)(60)(8.337)}{(3,785)}=57.6$ 音/ $/ \mathrm{hr}$.

Frue Latent flest $961.6 \mathrm{Bth} / \mathrm{lb}$.

$(57.6)(961.6)=55,38.0$ Btu. $/ \mathrm{hr}$.

Heat Loss from eurre of $\mathrm{PLg}$. 3 for this run amounts to $17,920 \mathrm{Etu} / \mathrm{hr}$.

Net Heat: $55,388.0-17,920=37,468$ Bu. $/$ br. 
$L$ LWD $=\frac{(225.7-132.2)-(225.7-162.5)}{\ln \frac{87.5}{63.2}}=75.5^{\circ} \mathrm{T}$

$0=\frac{(37.468 \mathrm{Btu} / \mathrm{hr} .)}{(11.69 \mathrm{ft} .2)\left(75 . \mathrm{F}^{3} \mathrm{~F}_{.}\right)}-42.45 \mathrm{Btu.} / \mathrm{hr} .-1 t .8-\mathrm{O}_{\mathrm{F}}$

overall Heat iranerer Coeffi ei enta

(b) Besed on Liquia side inthalpies: hun 7

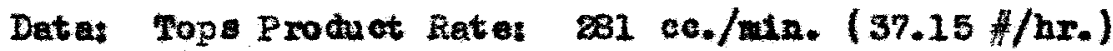

Bottons Product Rates 3.0 ce./min. $(0.40$ \#/mr.)

Feed Temperature: $138,2 \%$.

Eottons peaperature: $162.5^{\circ} \mathrm{T}$.

Stesan Tenperature: $225.7-I$.

Searible heat to Vepor: $(37.15)(212-138.2)=2749.1$ Eno.

Latent heat to Vagor: $(37.15)(970)=36035.5$ Btu./hr.

Semsible heat to Bottoms: $(0.4)(162.5-138.2)=9.72$ gtu. $/ \mathrm{hr}$.

Het Eeat: $2749.1+36035.5+9.72=38,794.3$ Btu. $/ \mathrm{hr}$.

D: $\frac{(39.794 .5)}{(11.69)(75.5)}=43.95$ Btu./hr. $-14.2-0$.

(3) Corralation I

Data: Feed Rate: $530.0 .4 / \mathrm{hr}$.

Bottoms Rate: 471.95 If/hr.

(5ottons/Feed) $=0.8905$

In (Bot tand 4 (Fed) $=-0.116$

The area on a plot of " $x "$ "ts $"(1 / y-x)$ " counting from "xeed" of 4.024

wt. I equal to the velue -0.116 has a calculated composition of

1.575 . 5 . 
(4) Evaluating the equation eonstents as chow on pazo 34.

Two points are choden from the ourve of $\mathrm{HI}$. 9, as,

xatual

$x_{\text {cal an ated }}$

0.076

0.29

2.300

4. 20

Substituting these ralues in the general equation of the eurre shown gives:

$$
0.29=(0.076)^{\mathrm{m}} \text { and } 4.2-a(2.8)^{\mathrm{z}}
$$

Solution by simbltancous equation gives:

$$
\begin{aligned}
1080.29 & =108 \mathrm{a}+108(0.076) \\
-1.238 & =108 \mathrm{a}+(-2.579) \\
1084.2 & =108 \mathrm{a}+108(2.8) \\
1.43508 & =108 \mathrm{a}+(1.02982) \\
2.67308 & =1(3.60862) \\
\mathrm{m} & =0.7405 \\
1.4351 & =108 \mathrm{a}+0.762 \\
\mathrm{a} & =1.96
\end{aligned}
$$


Table $X(a)$ - Date on Water Runs

\begin{tabular}{|c|c|c|c|c|c|c|c|c|}
\hline \multirow[b]{2}{*}{$\begin{array}{l}\text { Rum } \\
\text { No. }\end{array}$} & \multirow[b]{2}{*}{$\begin{array}{c}\text { Feed } \\
\text { Rete } \\
(\text { C.P.E. })\end{array}$} & \multirow[b]{2}{*}{$\begin{array}{c}\text { Stean } \\
\text { Rate } \\
\text { (h/hr.) }\end{array}$} & \multirow[b]{2}{*}{$\begin{array}{c}\text { Procuet } \\
\text { Tops } \\
(\# / \mathrm{hr} .)\end{array}$} & \multirow[b]{2}{*}{$\begin{array}{l}\text { Retea } \\
\text { Bot toms } \\
\text { (H/hr.) }\end{array}$} & \multicolumn{4}{|c|}{ Temperatures } \\
\hline & & & & & $\begin{array}{l}\text { Feed } \\
\text { g. }\end{array}$ & 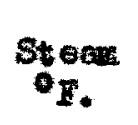 & $\begin{array}{c}\text { Bot toms } \\
{ }_{1} \text {. }\end{array}$ & $\begin{array}{c}\text { LurD } \\
{ }^{\circ} \mathrm{F} .\end{array}$ \\
\hline W-1 & 11.20 & 45.00 & 22.00 & 68.00 & 195.8 & 218.4 & 188.6 & 26.0 \\
\hline-2 & 21.60 & 8.3 .80 & 49.64 & 48.91 & 137.1 & 225.8 & 199.4 & 51.4 \\
\hline $1-5$ & 21.44 & 82.10 & 42.50 & 127.24 & 136.9 & 225.8 & 208.9 & 43.4 \\
\hline$w-4$ & 13.50 & 59.75 & 44.29 & 7.39 & 137.3 & 225.8 & 192.2 & 56.8 \\
\hline$x-5$ & 12.60 & 58.56 & 42.83 & 66.76 & 140.9 & 225.8 & 192.2 & 55.3 \\
\hline$w-6$ & 12.60 & 57.42 & 42.04 & 65.32 & 139.6 & 225.9 & 192.2 & 56.0 \\
\hline 19 & 4.10 & 57.51 & 37.15 & 0.40 & 128.2 & 225.7 & 162.5 & 75.5 \\
\hline $4-8$ & 3.20 & 50.77 & 50.80 & 0.00 & $13 \mathbf{2 . 0}$ & 285.7 & 212.0 & 41.9 \\
\hline $1-9$ & 22.25 & 56.85 & 32.60 & 154.81 & 139.1 & 225,6 & 201.2 & 49.0 \\
\hline$w-10$ & 21.82 & 56.85 & 30.93 & 152.29 & 136.4 & 225.8 & 201.2 & 50.2 \\
\hline-11 & 22.71 & 56.58 & 29.88 & 151.24 & 135.5 & 225.6 & 201.2 & 50.3 \\
\hline$n-12$ & 33.05 & 57.37 & 20.49 & 260.70 & 135.0 & 225.6 & 205.7 & 46.7 \\
\hline$n-13$ & 32.40 & 57.64 & 19.30 & 253.03 & 133.7 & 225.7 & 205.7 & 47.1 \\
\hline p-17 & 46.87 & 89.90 & 33.71 & 362.89 & 140.4 & 225.8 & 210.2 & 41.1 \\
\hline$k-18$ & 46.87 & 89.40 & 31.46 & 356.94 & 140.0 & 225.6 & 210.2 & $41 \cdot 2$ \\
\hline-19 & 46.76 & 86.59 & 31.46 & 365.93 & 138.6 & 225.8 & 210.2 & 41.6 \\
\hline$x-20$ & 15.70 & 85.93 & 50.90 & 80.11 & 138.2 & 225.8 & 174.2 & 67.9 \\
\hline 蚺 & 15.30 & 86.72 & 51.03 & 75.36 & 188.2 & 225.8 & 183.2 & 62.5 \\
\hline $6-22$ & 27.43 & 83.29 & 40.98 & 188.12 & $138 \cdot 2$ & 226.1 & 205.7 & 46.2 \\
\hline $1-23$ & 26.78 & $84 * 61$ & 40.98 & 178.75 & 138.2 & 225.6 & 206.6 & 44.8 \\
\hline $7-24$ & 26.24 & 86.99 & 42.30 & 169.61 & $138 \cdot 2$ & 226.1 & 206.6 & 45.4 \\
\hline $1-25$ & 25.92 & 86.19 & 49.45 & 170.54 & 138.2 & 225.7 & 206.6 & 45.0 \\
\hline
\end{tabular}


Table $X(a)$ - Data on Water Run (Cont.)

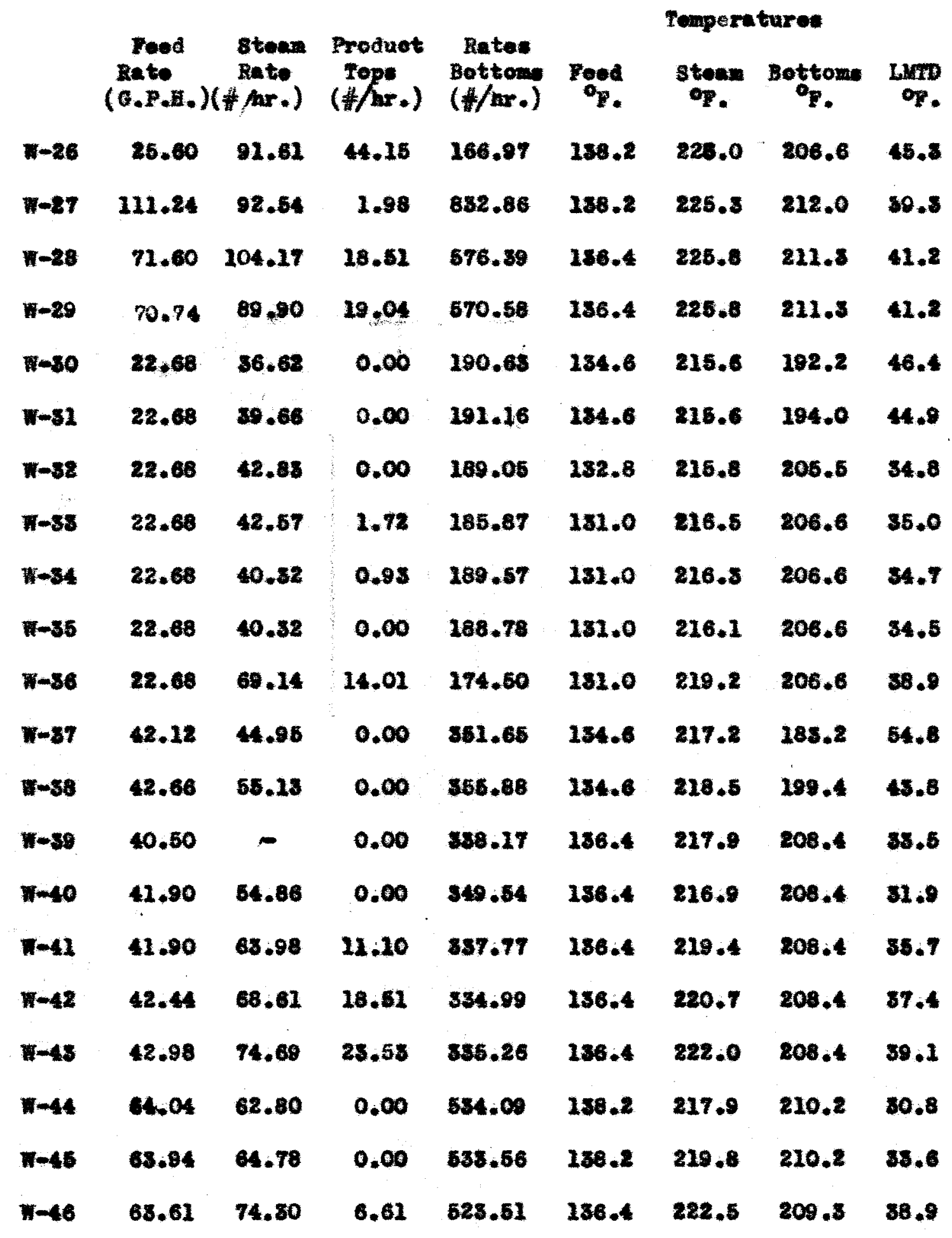


Fable $X(a)$ - Data on Nater Rune (Cont.)

\begin{tabular}{|c|c|c|c|c|c|c|c|c|}
\hline \multirow[b]{2}{*}{$\begin{array}{l}\text { Rum } \\
\text { No. }\end{array}$} & \multirow[b]{2}{*}{$\begin{array}{c}\text { Foed } \\
\text { Rate } \\
\text { (G.P.H) }\end{array}$} & \multirow[b]{2}{*}{$\begin{array}{c}\text { stoan } \\
\text { Rato } \\
(t / h r \cdot)\end{array}$} & \multirow[b]{2}{*}{$\begin{array}{c}\text { Produet } \\
\text { Tops } \\
\text { (thro) }\end{array}$} & \multirow[b]{2}{*}{$\begin{array}{l}\text { Ratos } \\
\text { Bottoms } \\
\text { (H/hr.) }\end{array}$} & \multicolumn{4}{|c|}{ Temporature: } \\
\hline & & & & & $\begin{array}{l}\text { Food } \\
\text { or }\end{array}$ & $\begin{array}{c}\text { stena } \\
\text { or. }\end{array}$ & $\begin{array}{l}\text { Bottome } \\
\text { o. }\end{array}$ & $\underset{\mathrm{Tro}}{\mathrm{u}}$ \\
\hline$\pi-47$ & 63.94 & 78.11 & 6.61 & 526.68 & 186.4 & 220.9 & 210.2 & 6 \\
\hline $7-40$ & 61.56 & 84.61 & 8.86 & 505.95 & 136.4 & 228.6 & 210.2 & \\
\hline$T-49$ & 107.46 & 84.87 & 0.00 & 1021.35 & 188.2 & 221.8 & 210.6 & \\
\hline$x-60$ & 107.08 & 86.98 & 0.00 & 951.84 & 138.2 & 221.8 & 210.6 & \\
\hline$x-51$ & 105.20 & 86.19 & 0.00 & 886.05 & 188.2 & 281.9 & 210.6 & \\
\hline $1-52$ & 104.76 & 86.10 & 0.00 & 884.42 & 188.2 & 221.9 & 810.6 & \\
\hline $7-53$ & 104.76 & 84.21 & 0.00 & 856.68 & 288.2 & 224.9 & 200.0 & It \\
\hline$V-54$ & 104.76 & 95.05 & 0.00 & 966.66 & 138.8 & 284.7 & .0 & 41 \\
\hline $7-58$ & 105.67 & 118.48 & 28.63 & 664.50 & 238.2 & 227.7 & 210.2 & 4. \\
\hline $7-56$ & 208.14 & 112.50 & 25.68 & 821.64 & 138.2 & 228.0 & 210 & 5 \\
\hline $1-57$ & 22.14 & 68.22 & 20.00 & 285.47 & 138.2 & 282.1 & 9 & 0 \\
\hline$n-68$ & .92 & 72.05 & 38.52 & 141.88 & 238.2 & 222 & 4 & 6. \\
\hline$n-59$ & 20.65 & 72.65 & 38.68 & 188.28 & $25 B .2$ & 222.1 & 200.3 & 6. \\
\hline $1-60$ & 20.20 & 69.80 & .62 & 186 & 138.2 & 22.1 & 200.3 & 0.1 \\
\hline$w-61$ & .72 & 81.08 & 42.70 & 138.56 & 188.2 & 225.0 & 20 & 6.4 \\
\hline$n-64$ & .88 & 61.08 & 21.05 & 168.28 & 38.2 & 221.1 & 0 & 8.0 \\
\hline $7-65$ & .98 & 88.84 & $18 \cdot 24$ & 8.07 & 88.2 & $227 \cdot 2$ & 3 & 4. \\
\hline$W-66$ & .09 & 65.44 & .01 & 350.38 & $138 \cdot 2$ & 219.3 & 208.4 & 5.0 \\
\hline$n-67$ & 42 & 65.44 & .01 & 360.38 & 88.2 & 219.7 & 108.4 & 6 \\
\hline $7-6$ & 09 & 79.08 & 3 & $\mathbf{b e}$ & 186 & 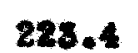 & $200 \cdot 2$ & 4 \\
\hline $1-60$ & 42.66 & 06.76 & 51.82 & 804.06 & 188.2 & 229.6 & $208 \cdot 4$ & \\
\hline
\end{tabular}


Pable $X(b)$ - Data on Water Runs

HEAT QUANTITIES ON STEAY BIDS

\begin{tabular}{|c|c|c|c|c|}
\hline $\begin{array}{l}\text { Fun } \\
\text { No. }\end{array}$ & $\frac{\text { In Stean }}{\text { Btu./hr. }}$ & $\frac{\text { Leat Lose }}{\text { te. } / \mathrm{hx}}$ & $\frac{\text { Net Steg }}{\text { Btu./hr. }}$ & 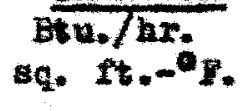 \\
\hline$w-1$ & 43479.00 & 12900 & 31579.00 & 103.90 \\
\hline $7-2$ & 80669.85 & 18090 & 62579.85 & 104.15 \\
\hline-3 & 79035,30 & 18090 & 60945.30 & 120.18 \\
\hline $5-4$ & 57497.70 & 18090 & 39407.70 & 59.35 \\
\hline-5 & 56440.05 & 18090 & 38350.05 & 59.32 \\
\hline$F-6$ & 55209,30 & 18100 & 37109.30 & 56.69 \\
\hline$=7$ & 55388.16 & 17920 & 37468.20 & 42.45 \\
\hline$n-8$ & 55676.64 & 17920 & 37756.64 & 77.08 \\
\hline $7-9$ & 57720.73 & 17790 & 39950.73 & 66.22 \\
\hline$w-10$ & 54805.50 & 18090 & 36715.50 & $\begin{array}{c}62.56 \\
:\end{array}$ \\
\hline $7-11$ & 54528.39 & 17790 & 36738.39 & 62.48 \\
\hline $\mathbb{N}-12$ & 55297.75 & 17790 & 37507.75 & 68.71 \\
\hline-13 & 55580.48 & 17092 & 37660.48 & 68.6 \\
\hline-17 & 86535.00 & 18090 & 68445.00 & 142.46 \\
\hline $9-18$ & $85958 \cdot 10$ & 18090 & 67868.10 & 140.91 \\
\hline $4-19$ & $83458 . \infty 0$ & 18090 & 65368.20 & 134.42 \\
\hline$x-20$ & 82785.15 & 18090 & 64695.15 & 81.51 \\
\hline-21 & 86563.04 & 18000 & 68563.04 & 94.14 \\
\hline $1-22$ & 80180.76 & 18260 & 61920.76 & 114.65 \\
\hline-23 & 81447.52 & 17840 & 63607.52 & 121.45 \\
\hline $1-24$ & 83737.94 & 18260 & 65477.94 & 123.37 \\
\hline
\end{tabular}
Bta./pr.
OVERALX CortincIuA OF HEA THANSTZR sq. $f t,-0$. 103.90 
Table $x(b)$ - Data on Water Rune (Cont.)

MAT QUAWTITES ON STMA BIDS

In stom

Rux

no.

w-85

w-26

$7-27$

V-28

W-29

$7-20$

$n-3$

$w-32$

(1) -5

T-84

$w-36$

T-36

$\mathbf{H - 5 7}$

T-3e

$n-89$

$w-10$

$\Psi-4$

$7-48$

$7-45$

$W-4$
Leat Lose

Btuphe.

17800

18240

17560

16090

18090

9600

9600

9700

20300

10100

10000

12480

10080

12000

11500

58196,00

61792.00

66274.89

72008.35

60792.85

11600 $\frac{\text { Hot stean }}{\text { Bta. } / \text { ma }}$

65086.08

70020.58

71608.13

82194.46

68445,00

25929.27

28838.57

31885 . 28

80919.76

28995.08

29090.12

64546.44

32685.00

41328.72

42556.00

49072.00

52594.80

57268.38

49292.85
OVIRALE. COEFTETEnt or un TRAISTER Btag/ne

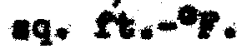

128.75

137.22

166.86

170.66

142.11

47.60

54.68

78.42

75.46

71.48

72.10

119.68

50.86

80.64

114.05

117.68

120.42

125.37

136.68 
Iable $X(b)$ - bata on wator fure - (Cont.)

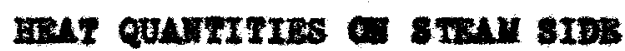

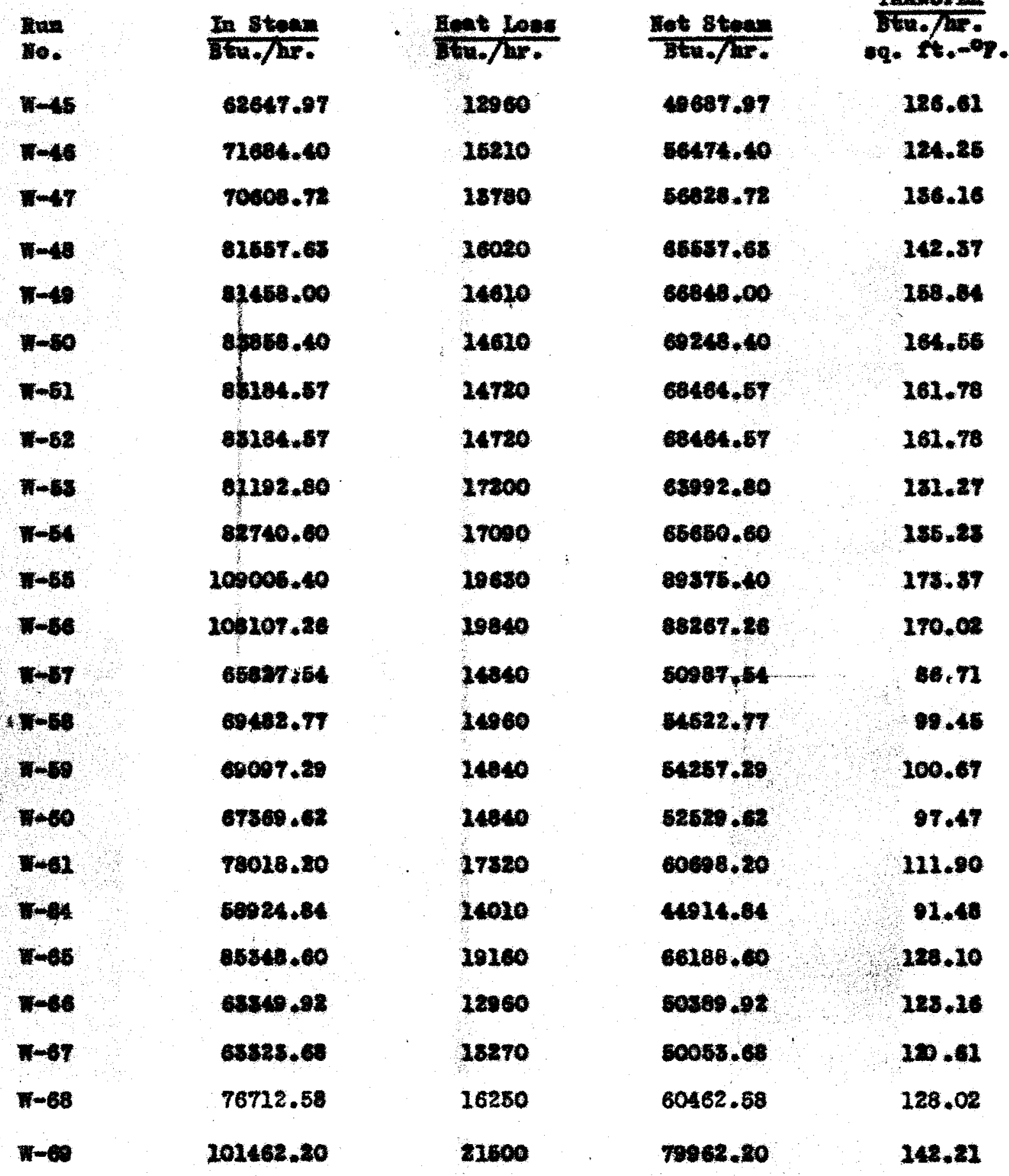
of incer Thusstan Bta./Tr. g. $4 .-9$.

126.62

124.86

164.65

161.78

162.78

28.27

173.87

170.69

4622.7

OTBRT. cosmorme

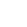


Table $\mathrm{x}(c)$ - Hoat Tranafor Baced on Hiquid side Data

Hat OLANTTES ON LTQUD SIDS

\begin{tabular}{|c|c|c|c|c|c|}
\hline $\begin{array}{l}\text { Iun } \\
\text { Ho. }\end{array}$ & $\begin{array}{c}\text { Tapor } \\
\text { (aeneible) } \\
\text { Bta. } / \text { hr. }\end{array}$ & $\begin{array}{c}\text { Vapor } \\
\text { (1atent) } \\
\text { Btu./mr. }\end{array}$ & $\begin{array}{c}\text { Bottom } \\
\text { (aonelbie) } \\
\text { Bta./hr. }\end{array}$ & $\begin{array}{l}\text { Not Heat } \\
\text { Btu. hr. }\end{array}$ & $\begin{array}{l}\text { Iranefor } \\
\text { Btu. } / \text { hr. } \\
\text { - ft. } 2-9\end{array}$ \\
\hline$x-1$ & 356.40 & 81840.00 & 489.60 & 28186.00 & 72.80 \\
\hline$x-2$ & 3723.00 & 18260.80 & 3047.00 & 54920.80 & 30.40 \\
\hline$t-8$ & 5181.75 & 11225.00 & 9261.28 & $68578.0 \%$ & 105.60 \\
\hline$x-4$ & 5808.46 & 42961.30 & 3919.31 & 60189.07 & 75.60 \\
\hline$x-5$ & 8040.98 & 42645.10 & 8424.79 & 48010.88 & 74.27 \\
\hline$w-6$ & 5026.08 & 40778.80 & 3435.81 & 47240.99 & 72.16 \\
\hline$n=7$ & 2749.10 & 56085.50 & 9.72 & 38794.32 & 48.96 \\
\hline$N-8$ & 2494.80 & 29876.00 & - & 32870.80 & 66.00 \\
\hline $14-9$ & 2306.80 & 30652.00 & 9613.70 & 42572.50 & 74.82 \\
\hline$N-10$ & 2358.51 & 80002.10 & 9868.89 & 42208.80 & $\mathbf{7 . 9 8}$ \\
\hline $7-11$ & 8285.82 & 28985.60 & 9936.47 & 41205.89 & 70.08 \\
\hline$T-12$ & 1577.73 & 19876.80 & 18452.49 & 39084.52 & 78.06 \\
\hline 7 電-13 & 1511.19 & 18721,00 & 18218.16 & 38450.35 & 69.85 \\
\hline$w-17$ & 2413.64 & 32698.70 & 25329,72 & 60442.06 & 125.80 \\
\hline$x-18$ & 2266.12 & 30516.20 & $250: 7.19$ & 57838.51 & 120.09 \\
\hline क- 19 & 2309.16 & 30816.20 & 86200.59 & 50025.96 & 121.88 \\
\hline $7-20$ & 3756.42 & 49378.00 & 2083.96 & 66018.38 & 70.67 \\
\hline$x-21$ & 5766.01 & 10409.10 & 3890.76 & 56655,86 & 77.78 \\
\hline $7-28$ & 3024.32 & 39760.60 & 12698.10 & 55475.02 & 108.71 \\
\hline$x-23$ & 8024.32 & 39750.60 & 12226.18 & 56000.06 & 105.01 \\
\hline $4-24$ & 3121.74 & 41081.00 & 11601.38 & 55764.06 & 205.05 \\
\hline
\end{tabular}

Cooffloient of lleat Irancfor Btu. $/ \mathrm{hr}$. Btu. hr. 28186.00 
Fable I (e) - Heat Trancfer Baced on Liquid side Date (Cont).

BRAT QUANTITIES OH LIQUTD SIDS

Vapor Vapor Bottome

Eun

10.

v-25

w-26

W-27

$\overline{n-28}$

$7-29$

$-30$

พ-51

$\pi-52$

W-s8

$n-34$

W-56

$\pi-36$

W-57

$\mathbf{n - 5 8}$

$7-39$

$v-40$

$w-41$

$w-42 \quad 1399.36$

$7-45 \quad 1778.87$

$7-44$

$N-45$ (coneibie)

Btu. hr.

2985.21

5258.27

146.12

1399.86

1488.42
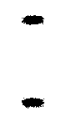

129.32

$\mathbf{7 6 . 8 3}$

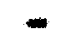

1184.81
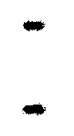

$-$

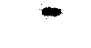

889.16

10787.00

27854.70

22824.10

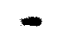

-

42826.50

1920.60

17854.70

18468.00

$-$

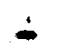

-

1688.40

902.10

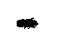

$13589 \cdot 70$
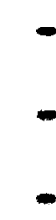

(1atont) (aonetb2e)

Btu./ne. Btu./hr.

$89286.50 \quad 11664.84$

$\begin{array}{cr}- & 25166.88 \\ 10767.00 & 24319.44 \\ 27954.70 & 24119.28 \\ 22824.10 & 24138.72 \\ - & 38454.48 \\ - & \$ 8416.32\end{array}$

Not Eeat

Btu. $/ \mathrm{hr}$.

68886.65

67604.62

63681.70

62625.67

62644.68

10080.29

11854.90

13748.04

15869.49

15808.92

14271.77

27926.71

17000.10

93061.08

24348.24

25166.88

35926,60

4347.34

48742.69

38464,48

88416.82
Coarflatont of Host Transfor Btu. hr. $-x^{2}-{ }^{\circ}$. 202.44

108.69

188.29

129.82

180.07

20.24

21.62

88.80

88.72

37.74

85.41

61. 47

26.68

46.00

62.16

67.45

86.16

99.54

106.72

106. 78

97.80 
Table $\mathbf{X}(e)$ - heat Trancfor Baved on Liquid side Data (Cont.)

HWT GUATITIES OI LIQUID SIDS

\begin{tabular}{|c|c|c|c|c|c|}
\hline $\begin{array}{l}\text { Ruan } \\
\text { No. }\end{array}$ & $\begin{array}{c}\text { Taper } \\
(\operatorname{coneible}) \\
\text { Bta./pr. }\end{array}$ & $\begin{array}{c}\text { Veper } \\
\text { (1atont) } \\
\text { Btu. Mr. }\end{array}$ & $\begin{array}{l}\text { Bottone } \\
\text { (conelbie) } \\
\text { Btu./ar. }\end{array}$ & $\begin{array}{l}\text { yot Hoat } \\
\text { otu. } / \mathrm{Mr} \text {. }\end{array}$ & 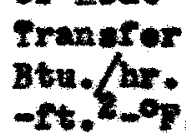 \\
\hline$n-46$ & 198.72 & 6411.70 & 88168.80 & 45075.80 & 90.17 \\
\hline $7-47$ & 490.72 & $6411 \cdot 70$ & 80860.98 & 46780.40 & 109.70 \\
\hline $7-40$ & 669.82 & 8594.20 & 57191.61 & 46455.53 & 100.01 \\
\hline $7-10$ & - & - & 73220.29 & 73220.29 & 178.99 \\
\hline$T-60$ & - & - & 68913.28 & 68913.22 & 168.75 \\
\hline $1-51$ & - & - & 60528.67 & 60588.57 & 248.08 \\
\hline $1-52$ & - & - & $6403 \% .01$ & 64082.01 & 262.31 \\
\hline$W-58$ & - & - & 60851.63 & 60651.58 & 124.42 \\
\hline$x-54$ & - & - & 60651.68 & 60651.53 & 124.93 \\
\hline W-55 & 2756.51 & 22824.10 & 62250.48 & 66821.09 & 168.89 \\
\hline$N-56$ & 1786.51 & 22824.10 & 58014.08 & 83574.69 & 160.98 \\
\hline $7-57$ & 2140.10 & 28207.60 & 8757.41 & 80091.11 & 66.48 \\
\hline$\Psi-58$ & 2899.88 & 32544.40 & 8689.18 & 42683.66 & 77.76 \\
\hline $\boldsymbol{W - 5 9}$ & 2478.20 & 32572.60 & 8687.10 & 48687.80 & 60.80 \\
\hline$n-60$ & 2899.98 & 31844.40 & 84.4 .46 & 42391.84 & 78.66 \\
\hline $7-61$ & 3151.86 & 41419.00 & 0108.74 & 53675.00 & 98.95 \\
\hline $15-64$ & 2610.92 & 21291.60 & 10579.78 & 38491.10 & 68.21 \\
\hline$\pi-65$ & 1346.11 & 17692.80 & 22614.78 & 41658.60 & 80.62 \\
\hline $\mathrm{n}-66$ & 517.84 & 6799.70 & 24593.17 & 52910.21 & 77.99 \\
\hline$w-67$ & 527.84 & 6799.70 & 24508.17 & 32920.21 & 76.80 \\
\hline $7-68$ & 2736.62 & 22324.10 & 23627.92 & 46188.58 & 108.08 \\
\hline W-69 & 8824,32 & 50265.10 & 21345.01 & 75434.73 & 284.16 \\
\hline
\end{tabular}

Coorfioient of Eoat Iraneter Btu. hr. (Intent) (sonelbie)

Het Hoat 
Table II - Date on Nloohol Runs

\begin{tabular}{|c|c|c|c|c|c|c|c|}
\hline \multirow[b]{2}{*}{$\begin{array}{l}\text { Bun } \\
\text { Se. }\end{array}$} & \multirow{2}{*}{$\begin{array}{l}\text { Peed } \\
\text { nete } \\
\text { Hat }\end{array}$} & \multirow{2}{*}{$\begin{array}{c}\text { Tope } \\
\text { Eroduet } \\
7 / \text { hr. }\end{array}$} & \multirow{2}{*}{$\begin{array}{l}\text { Botton: } \\
\text { Produet } \\
\text { Plat. }\end{array}$} & \multicolumn{2}{|c|}{ Tomperatures } & \multirow[b]{2}{*}{ Yapor } & \multirow[b]{2}{*}{$\frac{\text { Luxt }}{\mathrm{V}}$} \\
\hline & & & & Foed & $\frac{\text { Bottoma }}{\text { o. }}$ & & \\
\hline$M-2$ & 226.2 & 42.30 & 279.79 & 140.0 & 203.0 & 208.6 & 4.0 \\
\hline$A A-2$ & 182.4 & 48.91 & 138.26 & 134.6 & 201.8 & 208.6 & 47.6 \\
\hline $\mathbf{A}-\mathbf{6}$ & 376.0 & 50.50 & 327.35 & 134.6 & 207.6 & 205.4 & 41.1 \\
\hline$\Delta A-4$ & 556.0 & 48.12 & 506.35 & 234.6 & 208.4 & 203.2 & 40.1 \\
\hline $\mathbf{M}-\mathbf{5}$ & 176.7 & 58.70 & 116.34 & 134.6 & 194.0 & 209.6 & 56.0 \\
\hline$\Delta \mathbf{A}-6$ & 370.0 & 60.55 & 308.08 & 184.6 & 207.3 & 207.3 & 44.7 \\
\hline$M-7$ & 530.0 & 57.64 & 471.95 & 134.8 & 208.4 & 205.0 & 46.8 \\
\hline $\mathbf{A}-\mathbf{B}$ & 165.0 & 47.86 & 122.95 & 134.6 & 201.2 & 200.6 & 46.8 \\
\hline $\mathbf{A}-\mathbf{9}$ & 866.0 & 57.37 & 313.51 & 184.6 & 208.4 & 207.6 & 10.1 \\
\hline$\Delta M-10$ & 178.2 & 48.10 & 129.66 & 105.8 & 198.6 & 200.0 & 59.0 \\
\hline $4-11$ & 349.0 & 40.59 & 308,05 & 105.8 & 207.3 & 205.5 & 50.6 \\
\hline$\Delta-18$ & 580.0 & 35.96 & 495.76 & 105.8 & 208.4 & 202.1 & 49.2 \\
\hline $\mathbf{M}-\mathbf{2 8}$ & 168.8 & 63.46 & 98.86 & 111.2 & 194.0 & 205.4 & 30.4 \\
\hline$M A-16$ & 349.0 & 83.65 & 264.40 & 111.2 & 204.8 & 199.4 & 0.6 \\
\hline $\mathbf{M}-16$ & 169.9 & 71.92 & 80.64 & 111.2 & 199.4 & 208.8 & 0.6 \\
\hline$M-16$ & 182.0 & 60.94 & 116.60 & 136.4 & 197.6 & 208.8 & 0.2 \\
\hline$M-17$ & 364.0 & 74.85 & 285.55 & 136.4 & 205.7 & 208.2 & 3.0 \\
\hline$M-18$ & 534.0 & 80.92 & 465.46 & 136.4 & 205.8 & 190.0 & \\
\hline
\end{tabular}


Fable XI - Date on Aloohol Runa (Cont.)

\begin{tabular}{|c|c|c|c|c|c|c|}
\hline $\begin{array}{l}\text { Rum } \\
\text { No. }\end{array}$ & $\begin{array}{c}\text { Letent } \\
\text { Leat } \\
\text { or Vupor }\end{array}$ & $\begin{array}{l}\operatorname{mar} \\
\text { sonsible }\end{array}$ & $\begin{array}{l}\text { VAPOR } \\
\text { Iatent }\end{array}$ & $\begin{array}{l}\text { Deat } 70 \\
\text { Bottone }\end{array}$ & $\begin{array}{c}\text { Total } \\
\text { Feat } \\
\text { Traniferred }\end{array}$ & E \\
\hline$M A-1$ & 005 & 2901.78 & 38281.60 & 11327.40 & 58510.68 & 108.00 \\
\hline$\Delta L-2$ & 697 & 8619.34 & 43872.27 & 8877.78 & 66369.39 & 101.80 \\
\hline$M-$ & 854 & $5675 \cdot 40$ & 48227.00 & 23860.17 & 70562.67 & 246.86 \\
\hline$\Delta-4$ & 647 & 3501.08 & 40757.64 & 87579.00 & 61437.67 & 178.75 \\
\hline$\Delta A-5$ & 912 & 402.80 & 53584.40 & 600.28 & 64846.12 & 99.08 \\
\hline $4-6$ & 872 & 4505.90 & 52790.88 & 22391.60 & 79877,68 & $152 * 29$ \\
\hline$A-7$ & 865 & 4067.86 & 49858.60 & 34838.60 & 88799.62 & 167.69 \\
\hline $4 a-8$ & 899 & $\$ 589.60$ & 43026.14 & 8188.47 & 54604.11 & 101.25 \\
\hline$\Delta A-9$ & 871 & 4184.46 & 49906.40 & 23128.92 & 77308.78 & 164.92 \\
\hline$A A-10$ & 805 & 4447.92 & 89006.60 & 12010.21 & 56465.63 & 80.42 \\
\hline$A A-11$ & BTs & 4035.86 & $\$ 5402.80$ & 31262.00 & 70698.36 & 119.52 \\
\hline $14-28$ & 860 & 8462.96 & 30025.60 & 50889.60 & 85278.16 & 148.27 \\
\hline$A=-13$ & 846 & 5978.87 & 53685.62 & 7758.50 & 67432.06 & 96.50 \\
\hline $\mathbf{A}-\mathbf{2 4}$ & 788 & 7375.52 & 65876.80 & 24747.80 & 97998.16 & 166.67 \\
\hline $4 A-16$ & 802 & 6064.08 & 62891.60 & 7117.70 & 75875.42 & 107.10 \\
\hline$\Delta-16$ & 888 & 4289.47 & 51912.86 & 7186.92 & 65357.76 & 107.98 \\
\hline$M A-17$ & 800 & 4916.99 & 58872.00 & 19790.01 & 84587.99 & 168.28 \\
\hline AA-18 & 780 & 5004.87 & 63200.80 & 31469.48 & 29644.20 & 198.28 \\
\hline
\end{tabular}


Ac montsoeiant 
The anther wiahes to exprest his appreeletion to Joeoph $\mathrm{B}$.

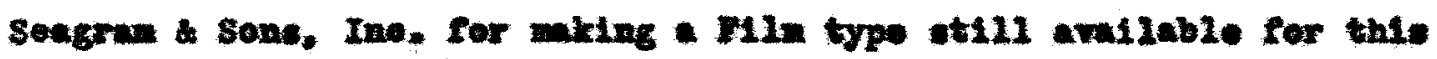
recouroh puoject. 
vrw 
Etward Jooph Etwal wa born of Albort Joseph and Louleo

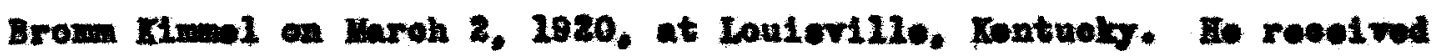
his primary oduoation at 8t. Joeoph Paroohiel sohool, his ceoondary tratuing at 8t, Inver High sohool, and his college training at the

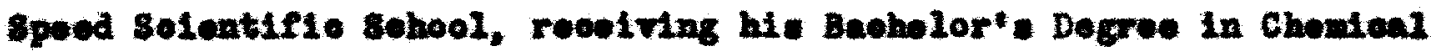
Bngineoring in My, 1942. He entered the night divialon of Ldult Gduoation in July, 1948, and rooefred his Uater's Dogree in chomical Enginoering from the Onivereity of Loulorille in Maroh, 1947. After completion of his udirgraduate work, Hr. Hamel ontered the omploy of the B. F. Goourioh Co., Loulmille, Iontuely. whore bo obtuinod com ground work in tho rield of inductrial plantion. In Oetober of 2845, he jolned the staff of the Joseph E. Seagram sone. Ino. Butadiemo Plot Plant Projest. After the termination of the rubber renearch progran, he wa trancferred to the Beagram lecearoh Laboratorios es Receareh and Development Engineor. Later, ho we

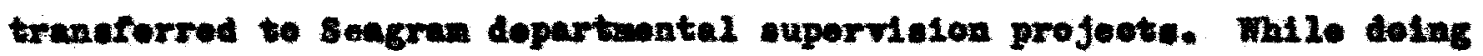
his udergreduate wori, be partielpated in Intranaral athleties, wae - four yoar naber of the Gniverelty of Loulerille Band, and wa eleoted to the natlowal honorary woolety of Thets ChI Delta.

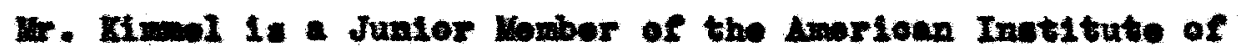

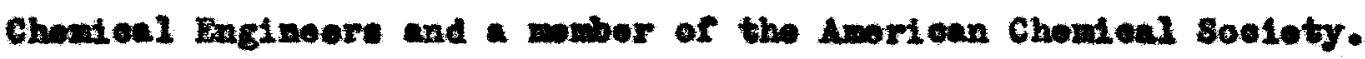

